\title{
What Do the United States and India Have in Common (Besides Indians): Enough for a Strategic Alliance?
}

\author{
Kern W. Craig ${ }^{1}$ \\ ${ }^{1}$ Department of Political Science, Troy University, United States \\ Correspondence: Kern W. Craig, Department of Political Science, Troy University, Troy, AL 36082, United \\ States. E-mail: kcraig38002@troy.edu
}

Received: October 1, 2012 Accepted: October 27, 2012 Online Published: January 28, 2013

doi:10.5539/ass.v9n2p70

URL: http://dx.doi.org/10.5539/ass.v9n2p70

\begin{abstract}
The United States and India have much in common (besides Indians), enough in fact to constitute a comprehensive alliance. Both countries are former British colonies. Both use the English language: unofficially but more in the US; and, officially but less in India. Both are complimentarily large, the US in terms of area and India in terms of population. The people of India are however younger and poorer. Both countries have long coastlines and together they are adjacent the major oceans of the world: Pacific, Artic, and Atlantic including the Gulf of Mexico; and, Indian including the Arabian Sea and Bay of Bengal.

The United States of America and the Republic of India have now converged as welfare states. The US was once more capitalistic whereas India was once more socialistic. Both countries use Affirmative Action: for minorities and women in the US; and, for Scheduled Castes, Scheduled Tribes, and Other Backward Classes in India. Both governments are secular but the US is predominately Christian whereas India is predominately Hindu. Both countries face the threat of Islamic terrorism particularly the US vis-à-vis Afghanistan and India vis-à-vis Pakistan. And both the United States and India must contend with the new super-state, China.
\end{abstract}

Keywords: United States, India, affirmative action, terrorism, nuclear proliferation, alliance

\section{Introduction}

The United States and India have much in common (besides Indians), enough in fact to constitute a comprehensive alliance. Both countries are former British colonies. Both use the English language: unofficially but more in the US; and, officially but less in India. Both are complimentarily large, the US in terms of area and India in terms of population. The people of India are however younger and poorer. Both countries have long coastlines and together they are adjacent the major oceans of the world: Pacific, Artic, and Atlantic including the Gulf of Mexico; and, Indian including the Arabian Sea and Bay of Bengal.

The United States of America and the Republic of India have now converged as welfare states. The US was once more capitalistic whereas India was once more socialistic. Both countries use Affirmative Action: for minorities and women in the US; and, for Scheduled Castes, Scheduled Tribes, and Other Backward Classes in India. Both governments are secular but the US is predominately Christian whereas India is predominately Hindu. Both countries face the threat of Islamic terrorism particularly the US vis-à-vis Afghanistan and India vis-à-vis Pakistan. And both the United States and India must contend with the new super-state, China.

This paper is essentially a primer on India and US-India relations written from an American point of view. It is comparative but nonetheless focused on India. The level of analysis is national because sovereign states are still the principal actors on the world stage (Ataman, 2003, p. 42). "No single approach can capture all the complexity of contemporary world politics ... (but) the study of international affairs is best understood as a protracted competition between the realist, liberal, and radical traditions" (Walt, 1998, p. 30). The author is a realist who acknowledges that anarchy is the natural state of affairs. The author is also a liberal (in the best sense of the word) who believes in democracy and capitalism. The author is therefore not a radical who believes in socialism, either communism or fascism. As a result, this paper is prescriptive as well as descriptive.

Many important issues are addressed in this work. There are separate sections dedicated to the history of India, language, size in terms of area and population, the brain drain, Indian Americans, federalism, the mixed economy, concentrated ownership, the energy bind, the green revolution, public education, misadministration, 
dependency theory, affirmative action, the war on terror, the China factor, and nuclear proliferation. In the conclusion, there is a discussion of US-India diplomacy. And well over a hundred sources are listed in the reference section. This work is dedicated to prosperity and peace. It therefore advocates better governance in both the United States and India as well as better relations between these two important countries.

\section{The History of India}

\subsection{Ancient History}

It is almost as difficult to explain the past as it is to predict the future. But, for better or for worse, the history of India is conventionally divided into three periods: the ancient or Hindu period, the medieval or Muslim period, and the modern or British period (Goel, 1994, p. 8).

There is some speculation that "Western historians cooked up the theory of an Aryan invasion of India around 1500 BC" (ibid). But it appears that there was in fact a "migration into Northwest India of nomadic herding tribes from Iranian plateau; (and) Indo-European language development; (with) oral religious traditions preserved in Vedas, (the) oldest of which, the Rig Veda, predates migration" (Time Line of India, 2012). "If history, as distinct from archaeology, is the study of the human past from written sources, then India's history begins with the Aryans ... the Rg Veda and ... the Vedic hymns ... still recited at weddings and funerals, and in the daily devotions of the brahman" (Basham, 2004, p. 31).

This much is known with greater certainty although some of the dates are approximate. Cyrus the Great (558-530 BC) expanded the Persian Empire from Greece to India. But, after 380 BC, the grip of Achaemenid dynasty weakened. In 327 BC, the Persians under Darius III were conquered by the Macedonians under Alexander the Great. And his armies subsequently invaded India. Following Alexander's death in $323 \mathrm{BC}$, the Greek satraps were defeated by Chandragupta Maurya, founder of the Maurya Empire (321-185 BC). Then, in 156-153 BC, India was invaded by the Bactrian Greek, King Menander, whose rule extended down the western coast (Smith, 1914, p. 213-215). Trade between India and Rome began around 1 CE, during the reign of Augustus (Sanujit, 2011).

"At the beginning of the Christian era no part of India was included in the Parthian empire ... (but) "about 20 AD,Azes II is supposed to have been succeeded by Gondophares who seems to have conquered Sind and Arachosia, making himself master of a wide dominion" (Smith, 1914, p. 230). "Petty Parthian principalities may have continued to exist for some time ... in the delta of the Indus ... probably towards the close of the first century after Christ" (ibid). "Special interest attaches to the Indo-Parthian king Gondophares because his name is associated in very ancient Christian tradition with that of St. Thomas (also known as Doubting Thomas), the apostle of the Parthians" (ibid, p. 231). But the ancient history of India is sketchy. And more than a little doubt surrounds the apostle's mission to the east.

Both the Scythians and the Kushans invaded and occupied the northwest parts of greater India around the time of Christ. "The arrival of the Yueh Chih, or Kushan, people in India was a result of their defeat at the hands of Shih Huang-ti of the Ch'in dynasty in China. Expelled from their traditional lands, the Kushan migrated west and defeated the Scythians of central Asia, who in turn attacked India at the time of the declining Mauryan Empire. The Scythians, or Sakas, carved out a kingdom of their own in the area around modern Afghanistan, including parts of northern India. They were supplanted, however, by the Kushans ... (who) played a key role in international relations in the first two centuries C.E. because their position between the Roman Empire to the west and the Chinese to the east made them valuable middlemen for the beginning of the Silk Road linking the two worlds economically and, to an extent, philosophically" (Kushan Invasion of India, 2012).

The White Huns or "Hephthalites, people of obscure origins ... were called Ephthalites by the Greeks, and Hunas by the Indians ... (although) there is no definite evidence that they are related to the Huns ... (They) were an agricultural people with a developed set of laws ... living in Dzungaria (northwest China). They displaced the Scythians and conquered Transoxiana and Khorasan before $425 \ldots$ and invaded Persia ... They were driven out ... and ... defeated by Khosru I. The White Huns also invaded India ... extending their domain to include the Ganges valley. They temporarily overthrew the Gupta empire but were eventually driven out of India in 528 by a Hindu coalition" (White Huns, 2012).

The Gupta Empire (320-550 CE) was the "Golden Age" of classical civilization in India. The revival of Hinduism brought both peace and prosperity. The age began with the coronation of Chandragupta I and continued with the succession of his son. "The dominion of ... Samudragupta in the middle of the fourth century ... comprised all the most populous and fertile countries of Northern India ... while all the kingdoms of the south had been overrun by the emperor's armies" (ibid, p. 286). "The reign of Candra Gupta II perhaps marks the high water mark of ancient Indian culture ... (and) at this time India was perhaps the happiest and 
most civilized region of the world" characterized by "the rarity of serious crime and the mildness of the administration" but all of that was soon to change as "other invaders lost their fear of the Indian fighting elephant" (Basham, 2004, p. 66, 130).

\subsection{Medieval History}

The Muslim invasions of Southwest Asia roughly coincided with the Muslim invasions of Central Asia beginning in the $8^{\text {th }}$ century and with the Muslim invasions of Europe ranging from the Iberian Peninsula in 711 to the land between the Black and Caspian Seas in 1045. Islamic rule ended in Western Europe in 1492 with the expulsion of the Moors from Hispania and it ended in Eastern Europe in 1122 with the expulsion of the Seljuk Turks from Caucasia (David IV, 2012).

The first Muslim conquerors of India were the Arabs led by Muhammad bin Qasim who occupied Sindh in the $8^{\text {th }}$ century, the second were the Turks led by Aptigin who occupied Ghazni in the $10^{\text {th }}$ century, and the third were the Persians led by Muhammad Ghuri who occupied the Chauhan kingdom in the $12^{\text {th }}$ century (Goel, 1994, p. 8). A slave dynasty called the Delhi Sultanate was established early in the $13^{\text {th }}$ century under the rule of Qubtuddin Aibek and continued until the Mughal Empire was founded by Babar (or Babur), the grandfather of Akbar, in 1526 (Muslim Invasions, 2012).

"The Mughal empire ... expanded in all directions 'til by the end of the $17^{\text {th }}$ century it covered almost the whole of India except for the extreme south" (Goel, 1994, p. 74). It began to disintegrate when Aurangzeb reversed Akbar's policy of accommodation. And it "ended ... when the Marathas and the Jats and the Sikhs broke the back of Islamic imperialism in the middle of the $18^{\text {th }}$ century" (ibid, p. 18).

"Muslim rulers built ... many sumptuous palaces ... mosques and madrasahs ... now ... photographed by an endless stream of tourists ... (leaving) the impression that medieval India under Muslim rule was a many splendored land ... but so far as the Hindus were concerned, this period was a prolonged spell of darkness"(ibid, p. 18). As far as the Muslims were concerned, this period was a prolonged spell of domination. They sent "millions of kafirs (unbelievers) to hell in a continuous jihad (holy war) ... forcing the rest to eat beef ... collecting vast amounts of booty ... (and) capturing millions of men, women, and children and selling them into slavery ... over the far-flung Islamic world" (ibid, p. 17).

\subsection{Modern History}

Just as the medieval or Muslim period can be distinguished from the ancient or Hindu period, it can also be distinguished from the modern or British period. The contrast between Muslim rule and British rule is stark. "British rulers, though they encouraged Christian missionaries, never permitted them to convert Hindus by force ... they never desecrated Hindu places of worship or hurled insults at Hindu religion or culture ... (and) they frowned at but never prevented Indians from marrying British girls" (ibid, p. 15). Indeed, "it was through the influence of Europe that revival came" to India (Basham, 2004, 483).

Initially, it was "an empire driven less by the state than by the personal ambitions of people with vastly different backgrounds and agendas: from fortune-seeking gentry to merchants looking for new markets, impoverished economic migrants and evangelical missionaries" (Pondering the Past, 2012, p. 77). Although soldiers were employed, there was no military invasion and no war of conquest. "The British excelled at recruiting local elites and interest groups as collaborators without whose consent little would have been possible" (ibid).

"From 1757 to 1857 , the British exercised power through a London based corporation, the East India company ... (then, after) 1857, the British government exercised its rule directly until India became independent in $1947 \ldots$ and the only major domestic upheaval during the 190 year period of British rule ... occurred with the Uprising of $1857 \ldots$ the 'Sepoy Mutiny' ... set off by ... rumors that new cartridges supplied to the troops had been smeared with beef fat ... that was ritually unclean to practicing Hindus ... (or, alternatively,) pork fat which offended Muslims" (Sieff, 2009, p. 12).

The East India Company was different from the state owned enterprises (SOEs) so common in places like China today. It "controlled a standing army of some 200,000 men ... (even though) the British government did not own shares in the Company ... (and) it ruled millions of people from a tiny headquarters, staffed by 159 in 1785 and 241 in 1813" (Company that Ruled the Waves, 2011).

The East India Company began by offering limited liability to its shareholders and by securing a monopoly on trade with India. It prospered by establishing a feeder college, Haileybury, and by hiring on the basis of merit using standardized exams. But, as the years passed, the Company became more involved in Indian government and less involved in Indian business. Taxes gradually became more important than profits. Its subsequent insolvency resulted in a bail-out then a take-over by the British government. "Thus an organization that had been 
given life by the state was eventually extinguished by it" (ibid).

Both the United States and India are former British colonies. And Indians, misnamed by Christopher Columbus, have lived in the United States from time immemorial. So a distinction must be drawn between American Indians (including West Indians from the Caribbean) and East Indians.

In earlier times, both countries were solely occupied by aboriginal people. But indigenous groups lost out in the new world as well as the old. The native tribes of America were decimated by war, disease, and alcohol. Survivors ended up on reservations, remnants of their former land, or they assimilated into the new society through intermarriage with European settlers.

Likewise, the native tribes of the subcontinent broke "up under the pressure of Aryan culture ... chieftains were overthrown ... their lands and tribesmen absorbed into greater kingdoms" (Basham, 2004, p. 116, 248). In India, as in the United States, "wild tribesmen were a danger to the settled villagers in the outlying parts of the country ... pillaging crops, herds and houses, and capturing victims for human sacrifice" (Basham, 2004, p. 200).

The British exercised power over their American colonies until the Revolutionary War in 1776. After or at independence, both the United States and India fought wars of succession, classified as civil or international wars depending upon which side won. The Civil War in the US in 1861 resulted in victory for the Union forces of the north and defeat for the Confederate forces of the south but it also resulted in a $1 / 2$ million or more deaths.

The partition of British Indian Empire in 1947 resulted in the separation of Pakistan in the west from India in the east but it also resulted in a $1 / 2-1 \frac{1}{2}$ million deaths and 12-14 million refugees as Hindus fled from Pakistan and as Muslims fled from India (Sieff, 2009, p. 23). "The exchange of populations between the two new states took on the characteristics of what is today called 'ethnic cleansing"' (Gould, 2002, p. 148-9).

Britain was not involved in the Indian conflict as it was in the American Revolution 171 years earlier. Perhaps that is why India is a member of the British Commonwealth of Nations whereas the US is not. Indeed, the present Secretary-General is Kamalesh Sharma, an Indian diplomat (Who We Are, 2012). Fifty-four sovereign states are currently members of this voluntary association. And the US should at long last consider joining the club given its "special relationship" with the UK.

\section{Language}

Another "commonality with a difference" between India and the US involves language. Both countries use English: officially but less in India; and, unofficially but more in the US. In each country, English is part of the glue that holds a population together in spite of its diversity.

"The old official script of India was a Perso-Arabic one ... (but) Muslims wanted the national language ... to be Urdu ... (and) Hindus wanted to change it to Hindi ... (not much of a difference given that) Hindi and Urdu are virtually the same language, though Hindi draws more from Sanskrit, whereas Urdu takes from Persian and Arabic" (Sieff, 2009, p. 20). "Muslims started claiming Urdu as the language of their culture, and ... over the years" it was "heavily Arabicised and Persianised, and made more or less 'Greek' for the Hindus at large" (Goel, 1994, p. 110).

After the partition of India in 1947, Urdu was dropped and English was added. This left Hindi and English as the two official languages. "The Official Languages Amendment Act of 1967 ... provided for the following: (1) Hindi and English would be used in Parliament (and) ... (2) The central government would use Hindi in its communication with Hindi-speaking states and English for communicating with non-Hindi speaking states" (Chandhoke, 2007, p. 117).

Although "Hindi was the official national language, states could use their own official languages, and English would be the link" (Lal, 2006, p. 69). "The Eighth Schedule ... today ... lists twenty-two languages ... out of the 1,650 spoken ... (and) whereas Sanskrit with about 2,500 speakers finds place in the Eighth Schedule ... several tribal languages with millions of speakers do not" (Chandhoke, 2007, 117-119).

At present, "Hindi is ... spoken by about $30 \%$ of the population" (Christie, Kwon, Stoberl, \& Baumhart, 2003, p. 270). And, unofficially, there is a widespread use of "Hinglish, a hybridized language that combines Hindi and English" (Ghosh \& Chaudhuri, 2009, p. 8). In the United States, the situation is quite different. There is "no mention of an official language in the US Constitution ... (but) almost 94 percent of ... Americans speak English" (Chandhoke, 2007, p. 138, 126).

The dissemination of language usually follows the migration of people but not always. There are for example gypsies throughout Europe. In France they are called Gitanes, in Germany Zigeuner, in Hungary Cigany, in 
Romania Tigani, and in Spain Gitanos. The word "gypsy derives from Egyptian, from the supposed origin of the Roma ... (but) linguistic evidence indicates that the Roma came from India" (Home of the Roma Kings, 2012).In any event, there are not many Europeans speaking Romani today.

On the other hand, the sun never sets on the old British Empire and "English continues to spread from the UK, the US, Australia, Canada, Ireland, and New Zealand around the world" (Craig, 2012, p. 81). In "populous countries such as India, Pakistan, and ... Nigeria ... English is an official language, invariably used for international dealings and also, in most cases, for internal business" (Language of International Business, 1965, p. 9). There are more than 7,000 natural languages in the world today. "Of these ... about 80 are 'vehicular' languages, such as Chinese, Hindi, Spanish, and Arabic - languages learned by non-native speakers in order to communicate with native speakers of a third tongue. English, of course, dominates all of these" linguistic vehicles (Translation: Shape-Shifting, 2011) due to the spectacular success of British and American capitalism.

\section{Size Matters}

The US and India are complimentarily large, the US in terms of area and India in terms of population. In terms of area, the US is three times the size of India (including land covered by water). The area of the US is $9,826,675$ square kilometers whereas the area of India is 3,287,263 square kilometers (CIA, 2012). In terms of population, India is almost four times the size of the US (3.78 to be exact). The population of India is 1,173,108,018 whereas the population of the US is 310,232,863 (US Census Bureau, 2010). The people of India are also much younger and much poorer. But both countries are very diverse.

India, like the United States, has long coastlines. Over the long history of the subcontinent, "empires rose and fell, boundaries shifted and capitals moved. But India has remained, very nearly, the land bordered by the Himalayas to the north, the Indian Ocean to the south (the Arabian Sea in the west and the Bay of Bengal in the east), and great rivers" (the Indus in the northwest and the Ganges in the northeast) (Lines of History, 2012). But "many Hindus see India as an island surrounded by a (sea of) hostile Islam" (Glazer, 2007, p. 187).

Table 1. Population Statistics

\begin{tabular}{llll}
\hline Country & Overall Population & Muslim Population & Calculated Percent Muslim \\
\hline US & $310,232,863$ & $2,595,000$ & 00.8 \\
India & $1,173,108,018$ & $177,286,000$ & 15.1 \\
Pakistan & $184,404,791$ & $178,097,000$ & 96.6 \\
Bangladesh & $156,118,464$ & $148,607,000$ & 95.2 \\
Indonesia & $242,968,342$ & $204,847,000$ & 84.3 \\
China & $1,330,141,295$ & $23,308,000$ & 01.8 \\
\hline
\end{tabular}

As shown in Table 1 above: Pakistan has a population of 184 million that is 96.6 percent Muslim; Bangladesh has a population of 156 million that is 95.2 percent Muslim; and, India has a population of 1 billion 173 million that is 15.1 percent Muslim. Indonesia has the largest population of Muslims in the world followed by Pakistan, India, and Bangladesh (Pew Forum, 2011). The percentages for the United States and China are negligible by comparison. The statistics for overall population are taken from the US Census Bureau (2010) whereas figures for Muslim population are taken from the Pew Forum (2011). Both sets are for the year 2010.

The percent Muslim calculated here closely matches that calculated by the Pew Forum for the US, Pakistan, and China. But there is some difference for India (14.6), Bangladesh (90.4), and Indonesia (88.1).Using the Central Intelligence Agency's general population figures for July 2011, the percent Muslim is 0.8 in the US, 14.7 in India, 93.6 in Pakistan, 92.3 in Bangladesh, 82.5 in Indonesia, and 1.7 in China (CIA, 2011).

Using the general population figures from the United Nations for 2010-2011, the percent Muslim is 0.8 in the US, 15.0 in India, 107.8 in Pakistan, 101.4 in Bangladesh, 87.4 in Indonesia, and 1.7 in China (UN Statistical Division, 2009-2010). Such discrepancies are not however surprising given the inherent difficulties in conducting a national census, especially in large and/or poor countries (never mind the methodological differences between reporting agencies).

There are also problems in calculating "average population density, the most basic measure of population pressure ... the US population density in 2000 was only 30 people per square kilometer, a level substantially below the world average, but this masks large areas of much higher density ... (whereas) India's population density of 341 people per square kilometer puts it at almost eight times the average for the world but here too local densities vary widely" (Rain, Long, \& Ratcliffe, 2007, p. 322-323). Population pressure is obviously a 
much more serious issue in India than it is in the United States. The migration of people from an area of higher pressure to an area of lower pressure is therefore not surprising. And, in this instance, it is reinforced by a significant differential in economic opportunity. GDP per capita in India is $\$ 1,489$ compared to $\$ 48,442$ in the US (in current US dollars) (GDP per capita, 2012).

\section{The Brain Drain}

Indeed, there are Indians everywhere not just in the United States. The Indian diaspora is comparable to that of the Jews, the Brits, and the Chinese. "There is a substantial Indian community in South Africa ... (and) India's historical connections with South Africa add a unique dimension ... (inasmuch as) Mahatma Gandhi (1869-1948) first made his mark as a fighter for social and racial justice as a young lawyer in South Africa" (Schaffer, 2009, p. 182). Later, he returned to India as "the leader of ... non-violent resistance against British rule ... and against reckless industrialization" (Sharma, 2005, p. 175). In the US, Martin Luther King Jr. (1929-1968) was the "black Baptist (Christian) minister who followed Gandhian techniques for resisting racial oppression and was assassinated like Gandhi" (ibid, p. 176).

"India has had a mercurial relationship with the UK since independence (in 1947), but always an important one ... most importantly, the one million strong Indian community in Britain" (Schaffer, 2009, p. 179). "For a long time, India has been 'manufacturing' highly qualified human capital ... to be transferred ... to science and engineering higher education in Europe and North America; and from there, to a wide range of foreign, mostly American employers ... depriving India of the much needed technical expertise" (Ahmad, 2002, p. 62). This is not surprising. In India as elsewhere, "the rate of net migration per year is as strongly and significantly correlated (positively) with the annual gross domestic product per capita as it is (negatively) with rate of population growth per year" (Craig, 1995, p. 277). People vote with their feet if they are able to travel.

Nevertheless, people in India complain about the loss of talent while people in the United States complain about the displacement of domestic students and employees. In both countries, people tend to think in terms of zero-sum games with clear winners and losers (as in sports) instead of positive-sum games that are mutually beneficial (as in business). In other words, they tend to focus on absolute advantage and ignore comparative advantage resulting from specialization and trade.

The "brain drain" from India compliments the "tickle down" of capital as well as the "spin off" of technology from the United States. Although "Indian students and young professionals are flocking to the United States ... many of them come back to India with new skills and connections" (Schaffer, 2009, p. 112). Indeed, "a reverse migration of skilled persons from north to south is nowadays a discernible phenomenon ... (so) from brain drain theory, research has of late shifted focus to brain circulation" (Chaudhuri, 2011, p. 259, 249) discrediting yet another aspect of anti-capitalist dependency theory.

"American businesses are increasingly moving their research and development operations to India ... because a deficient US education system has resulted in a severe shortfall of engineers" (Wadhwa, 2008, p. 72). "The disadvantages of hiring US engineers ... (also include) salary demands" (Wadhwa, Gereffi, Rissing, and Ong, 2007, p. 75). Many North American firms outsource their "back office" operations to the sub-continent where employees accept not only lower wages but also speak English.

But "last year the Philippines ... overtook India, longest the biggest call-centre operator in the world, in 'voice-related services' ... (since) American customers ... have taken to complaining bitterly about Indian accents (which no amount of 'voice neutralization' coaching seems to have overcome) ... (yet in) the more sophisticated back-office jobs (in business-process outsourcing, BPO), such as those processing insurance claims and conducting due diligence ... called knowledge-process outsourcing and legal-process outsourcing, India still rules supreme" (At the Front of the Back Office, 2012).

Economic activity on the subcontinent has one foot in the past and one in the future. "India seems to prefer growing crops and selling services to making things you can drop on your foot ... (and) manufacturing is still just $15 \%$ of output, far below Asian norms" (Masala Mittelstand, 2012). At present, "India needs a big manufacturing base ... (since) nothing else is likely to absorb the labor of the $250 \mathrm{~m}$ youngsters set to reach working age in the next 15 years" (ibid). The "reckless industrialization" that Mahatma Gandhi complained about is exactly what India needs (Sharma, 2005, p. 175). An industrial revolution along with another green revolution would provide Indians with something to do as well as something to eat. The brain drain is a symptom not only of an exploding population but also of a sick economy. The government of India should administer a cure in the form of re-regulation, deregulation on the one hand to promote competition and regulation on the other hand to curtail corruption. 


\section{Indian Americans}

A distinction must be made not only between American Indians and East Indians but also between American Indians and Indian-Americans. "The Indian-American community ... (is) the third largest Asian-American population in the country, surpassed only by Chinese- and Filipino-Americans ... (and) the per capita income of Indian-Americans exceeds that of every other group in the country (including whites), except Japanese-Americans" (Hathaway, 2002, p. 391).

Joel Kotkin, in his book Tribes, counted the overseas Indians "along with the overseas Chinese, the overseas British, and the Jews as among the most dynamic entrepreneurial quasi-tribal ethic groups that were transforming the world's global economy" (Sieff, 2009, p. 113). "The largest number of Indian-Americans live in California ... (but) Maryland elected the first Indian-American state legislator, Kumar Barve, in 1990 ... (and) Louisiana elected the first governor, Bobby Jindal, in 2007" (Schaffer, 2009, p. 36).

In 1992, when "redistricting ... had thrown a large Indian-American population into his new congressional district ... New Jersey Democrat, Frank Pallone persuaded six other Democrats and ... (one) Republican ... to join him in Organizing a Congressional Caucus on India and Indian-Americans ... referred to as the India caucus" (Hathaway, 2002, p. 398-399). Lobbyists for India and Indian-Americans saw "the American Jewish community as an instructive role model" (Schaffer, 2009, p. 158).

"The American Association of Physicians of Indian Origin ... the Indian-American Friendship Council, the Asian American Hotel Owners Association and similar groups host legislative conferences in Washington each year ... (and) Indian-American political action groups - most notably the India Abroad Center for Political Awareness - have started ... placing interns in congressional offices ... (while) one community newspaper, India Abroad ... regularly features articles by members of Congress" (Hathaway, 2002, p. 392-393).

"As a whole, the (Indian-American) community has avoided identification with either of the major political parties and has given generously to both" (Hathaway, 2001, p. 24). "Democrats over the years have tended to support pro-India measures more often than Republicans" and "nearly three-fourths of the members of the India caucus are Democrats" (ibid, p. 402). But "African American legislators, nearly all of whom are Democrats, can almost always be found ... lambasting India's human rights record" (ibid, p. 29) equating caste with racism.

In the past, "congressional conservatives ... (have) been hostile towards India" (Rubinoff, 2002, p. 429). During the Old Cold War, they "saw a non-aligned India as unwilling to stand up and be counted in a struggle between the forces of freedom and those of servitude (ibid, p. 421). "Many ... were infuriated by India's veto of a ... 1951 General Assembly resolution that branded China as the aggressor in Korea" (ibid, p. 427).

"Nehru was viewed as 'clearly pro-Russian'- a characterization that was reinforced by the Indian position on Hungary" and its decision to abstain in the UN votes condemning the Soviet invasion of 1956 (ibid, p. 426). India was seen as "one of the 'persistently anti-United States members' in the United Nations, endorsing Soviet positions on Cuba, Kampuchea, Nicaragua, and especially Afghanistan” (ibid, p. 430-431).

But, over time, relations between India and the US improved to the point that good relations now transcend administrations. The improvement "began under the Democrats ... (in the US) and under Prime Minister Narasimha Rao in India, but it went equally well, if not better, with the BJP (Bharatiya Janata Party) and with President (George W.) Bush and the Republican Party ... (and) now the relationship has been picked up by President Obama and a longer-serving Congress coalition government under Prime Minister Manmohan Singh" (Pickering 2011). So not only are Indians benefiting from economic opportunities in America, India and the United States are enjoying much improved international relations.

\section{Federalism}

Federalism is another tie that binds each of these very diverse countries as democracies. The United States and India "have a number of important characteristics in common ... large populations (even though India is almost four times larger) ... federalism, a virtual necessity in very large countries ... judicial review with activist courts ... (and) highly diverse societies, although the religious and ethnic divisions in India are deeper and sharper" (Lijphart, 2007a, p. 11). "The US, in spite of its multicultural society, is more homogenous than India, its pluralism has little territorial bias ... Multiculturalism in the US ... (is) the result of large-scale immigration ... In India the multicultural characteristics are the result of a long history and have a distinctive territorial bias" (Linz, Stepan, \&Yadav, 2007, p. 74).

Although the official motto of the US is "In God We Trust," there is another motto on the front of the Great Seal of the United States: "E Pluribus Unum," from the Latin meaning "Out of Many, One (nation)." It is written on a scroll held in the beak of an American Bald Eagle (the national bird and emblem) with symbols for peace and 
war held in its talons, an olive branch and a bundle of arrows (13 representing the number of original states). On the back of the seal, there are two more Latin inscriptions: one denoting the eye at the top of a pyramid, reading "Annuit Coeptis" and meaning "He Favors Our Undertakings" and another at the bottom reading "Novus Ordo Seclorum" and meaning "New Order of the Ages." The year on the pyramid is written in Roman numerals, MDCCLXXVI, meaning 1776 (the year of American independence) (State Symbols USA, 2012).

"The model of social integration adopted by the USA has often been referred to as ... the 'melting pot,' while that of India has been ... described as the "mosaic"" (Sharma, 2005, p. 16). "Despite all the disparity, India and America share a strong bond of 'unity in diversity' which is celebrated as an integral part of their national identities" (Gaan, 2007, p. 35). "Historically, India was a collection of many kingdoms and peoples that ... were formally unified under the British Empire ... (and) with independence, former kingdoms and regions were given a voice in a federated system of parliamentary democracy" (Lal, 2006, p. 6). But "most Indians are still illiterate ... (and) most Indians don't know that they are ... Indian" (ibid, p. 72). Most continue to identify themselves by region and most are mired in poverty.

India and the US are both federal democracies but with many differences. India has a parliamentary / prime ministerial system whereas the US has a congressional / presidential system. India has a multi-party system whereas the US has a two-party system. India has "grand coalition governments" whereas the US has "winner-take-all ... bare-majority one-party governments" (Lijphart, 2007a, p. 4). Divided governments are however possible in the US when one party controls the Congress and the other controls the Presidency.

India's "party system ... is more competitive than most other established democracies, with more parties represented in parliament, and still more ... contesting elections at national and state levels ... (and) political parties ... function in a top-down style with the key decisions ... controlled by the party leadership" (Sridharan, 2007, p. 192). This "lack of internal democracy has been accompanied ... by repeated splits in major parties, and the frequent merger of small and new parties with other parties" (ibid, p. 193).

"Some voters are beginning to drift away from the rigid identity politics of old ... (but) nationally, Congress still gathers in the Muslim and more secular Hindu votes and the BJP the more fervent Hindus and (in many regions) caste still counts" (Aim Higher, 2012, p. 7). Identity politics likewise remains popular in the US with more women and blacks supporting Democrats and with more white men supporting Republicans. "Voting in India is generally clean and honest, but the campaigning is expensive and dirty" just as in the US (ibid).

In India, "the central government is weak due to coalition politics ... (and) populist regional parties hold the balance of power in parliament" (Silence of the Bollygarchs, 2012). America's party system is uniquely competitive inasmuch as primary elections "are an almost exclusively American phenomenon" (Lijphard, 2007b, p. 38). But US parties are "collections of candidate-centric structures" (Sridharan, 2007, p, 193) including not only the two major parties, Democrat and Republican, but also minor parties such as the Libertarian Party and the Green Party. In India, there are direct elections for President whereas in the US there are indirect elections. "The US presidential college (is in fact) the last ... electoral college ... in the world" (Lijphard, 2007b, p. 43).

In India, the Prime Minister rather than the President governs the country. "The Prime Minister is the leader of the majority party in the popularly elected Lok Sabha (lower house) or the member who has the confidence of a majority coalition" (Lal, 2006, p. 119). The United States has no Prime Minister due to its constitutional separation of powers between branches of government. It does however have numerous checks and balances or overlapping powers between its legislature, executive, and judiciary.

"The Indian Constitution ... is clearly not as rigid as the U.S. Constitution which is probably the most ... difficult Constitution to change in the world" (Lijphard, 2007b, p. 26). The first ten amendments to the U.S. Constitution were ratified a year after the Constitution itself was ratified. And, since that time, over two hundred years ago, there have been only seventeen additional amendments.

The legislatures in both India and the US are bicameral. "Lok Sabha members are elected to five-year terms, although the Lok Sabha may be dissolved prior to that time, leading to fresh elections ... (with) the allocation of seats to each state based upon population" (Lal, 2006, p. 120). In the US, House members are elected to two-year terms with the allocation of seats to each state based upon population. "The Rajya Sabha (upper house in India) has ... twelve members ... nominated by the President" (ibid, p. 120). Its remaining members are indirectly elected by state legislative assemblies. All serve six-year terms. In the United States, all Senators are directly elected by state residents and all serve six-year terms.

India and the US are different in terms of their electoral and party systems. They are also different with respect to the functions and structures of government, branches and levels. But levels of government are crucial in both 
countries. Decentralization is a primary means of dealing with diversity, whether it be ethnic, religious, or linguistic. The governments of India and the US are not only constitutional, democratic, and representative (or republican), they are also federal. In India, there are 28 states and 7 territories (States and Union Territories, 2012); and, in the US, there are 50 states and 5 territories (US Territories, 2012).

\section{The Mixed Economy}

East also meets West in terms of mixed economies. India and the US are now converging as welfare states. India was once more socialistic whereas the US was once more capitalistic. Today, governmental differences between the two countries are, for better and for worse, much less pronounced. Since the 1960s, the United States has morphed not only into a welfare state with an increasing number of entitlements but also into a police state with an increasing percentage of its population behind bars.

In the US, "the budget share of major mandatory spending programs - Social Security, Medicare, and health care programs for the poor - has more than tripled since the 1960s" (Perez, Horwitz, \& Kindall, 2012). And, in the US, the prison population rate is now the highest in the world at 730 per 100,000. That compares to only 216 per 100,000 in India (International Centre for Prison Studies, 2012).

The first independent prime minister of India, Jawaharlal Nehru (1889-1964) "set the nation upon the path of modern secular Socialism, with a planned economy, state ownership of major industries, and heavy controls" (Lal, 2006, p. 25). "The country's first batch of liberalizing reforms, in 1991, was precipitated by a balance-of-payments crisis" (Aim Higher, 2012, p. 4). And "the International Monetary Fund bailed out the nearly bankrupt nation" (Fodor's, 2011, p. 10).

"Since ... the 1990s, India has been moving away from socialist planning and embracing free-market economics" (Ganguly \& Scobell, 2005, p. 41). But it is still a massive welfare state. The government is "spending huge amounts in subsidies to individual beneficiaries" (India's Identity Revolution, 2011). Millions of Indians benefit from entitlement programs especially farmers.

At present, India is "supplementing an existing 'right to work' scheme concentrated on rural areas with a new 'right to food' scheme ... (and) next may come the roll-out of direct cash transfers into the bank accounts of welfare recipients ... made a lot easier by a 'unique identity' biometric scheme" (Unfinished Journey, 2012).The new right to food bill "would give two-thirds of the population a right ... to cheap food ... part of a trend (since) Indian law already promises the right to education, health and paid work" (Free Exchange, 2012).It is however as difficult to get a handout as it is to get a job. "One-fifth of adults and almost half of children younger than 5 suffer from malnourishment ... (because) "using dummy firms, local officials paid the government the subsidized price for the food (intended for the poor) ... then sold it to private companies at market prices" (India's Poor Starve, 2012).

"Some $40 \mathrm{~m}$ households benefit from a government scheme to provide up to 100 days work a year at the minimum wage, and the state has extended health insurance to some $110 \mathrm{~m}$ poor people" (Asia's Next Revolution, 2012). But the public works projects are a logistical nightmare. "Few poor people can prove who they are ... (since typically) they have no passport, no driving license, no proof of address ... (and) live in villages where multitudes share the same name" (Magic Number, 2012). And many of the under- or un-employed "(about 90\%) are in the 'informal' economy, making it harder to verify their incomes or reach them with transfers" (Asia's Next Revolution, 2012).

"The government pays for an $\$ 8$ billion-a-year make-work scheme for the rural poor, but much of the cash ends up in the capacious pockets of officials who invent imaginary 'ghost workers"” (Magic Number, 2012).The short-term solution is the Unique Identification (UID) biometric project. It permits the transfer of funds "directly to the account of the individual beneficiary electronically" (India's Identity Revolution, 2011). Recently, "Karnataka state claimed that by paying welfare direct to bank accounts it had cut some $2 \mathrm{~m}$ ghost labourers from a rural publics-works project" (Reform by the Numbers, 2012). "India's new health-care scheme for the poor aims to be cashless and paperless from the start, using swipeable smart cards to make payments and convey information" (Asian Welfare States, 2012). But many "worry that the voluntary (UID) programme will turn compulsory, that individual's privacy is under attack, and that biometric data are not secure" (Reform by the Numbers, 2012).

The long-term solution is of course more capitalism including not only less regulation of budding entrepreneurs but also more regulation of corrupt politicians. As it stands, the "nanny state" operating in conjunction with "big brother" results in an excessive concentration of power. The socialist state in India not only impedes economic progress, it also threatens personal freedom just as it does in the United States. 


\section{Concentrated Ownership}

There is a "highly concentrated ownership structure in the Indian market ... and Indian companies are dominated by families and promoter's stakes" (Srivastava, 2011, p. 23, 26). "A tradition of 'promoters' - as individuals or families with controlling stakes are known - can lead firms to borrow rather than dilute down their masters' stakes by issuing shares" (Hold Your Nose, 2012).

A prime example is Tata Sons, "a giant, complex 143-year old conglomerate under its fifth generation of family leadership ... (whose) acquisitions in Britain ... include Jaguar Land Rover" (Magical Mistry Tour, 2011). "The rapid globalization of Indian firms owes much to takeovers ... (but) their dislike of issuing equity for fear of diluting their controlling shareholders (interest) ... make(s) it hard to marshal resources without resorting to risky levels of debt" (Running with the Bulls, 2012).

On the subcontinent, "capitalism is skewed toward the state and business houses (conglomerates usually controlled by families and family trusts) ... State-backed firms, similar to China's, make $40 \%$ of stock market profits and dominate energy and finance ... remnants of India's Fabian nightmare" (Building India Inc, 2011). Corporatism can be just as bad as unionism but "it makes sense for businesses to sprawl because ... infrastructure is so awful that companies often build their own ... (and) courts are slow and sometimes corrupt, so contracts are hard to enforce and banks and business people are inclined to stick with companies they know and trust" (ibid, 2011).

Diversification like leverage can nonetheless be carried too far. And "investment, like trade, is primarily a private activity, with government playing a supporting role" (Schaffer, 2009, p. 33). Indian businesses should concentrate on their core competencies and rely more on equity and less on debt. The Indian government should deemphasize welfare and instead concentrate on public goods such as adequate infrastructure, e.g. highways, train tracks, bridges, ports, airports, etc. And it should privatize as many of its operations as possible. The government should mind its own business both by minimizing regulation and minimizing corruption.

Excessive debt is also problematic in the United States at both the individual and corporate level as are individual entitlements and corporate subsidies. Dilapidated infrastructure is a problem as well. The US suffers from concentration in the form of giant banks (like JPMorgan Chase, Bank of America, and Citi Group) and insurance companies (like AIG), financial firms that are simply too big to fail. The collapse of such a leviathan would severely injure the entire economy. The country also suffers from concentration in terms of major car companies (like General Motors and Chrysler) that are too unionized and too inefficient to succeed. The remedy for the US is the same as it is for India: less government regulation and subsidy and more business competition including dreaded foreign firms.

\section{The Energy Bind}

\subsection{Imported Oil}

The US and India both depend on imported oil even though India is more dependent than the US and more dependent on oil imported from the Middle East. "India is dependent on imports for some 70 percent of its oil ... (and) nearly 75 percent of India's crude oil imports originate in the states bordering on the Persian Gulf" (Vickery, 2011, p. 174). "About 57 percent of the petroleum ... consumed by the United States is from foreign sources ... (and) about 16 percent of the crude oil imported into the United States is from Persian Gulf countries" (ibid, p. 176).

The US and India are jointly "concerned about protecting the stability of their foreign sources and lines of supply ... particularly for the Persian Gulf region" (ibid, p. 177). And, "in the Middle East ... India has a common interest with the United States in preventing the rise of radical Islam" (Mohan, 2006, p. 25) since production cuts are an integral part of the ongoing holy war. Almost all OPEC members are Muslim countries, ten of twelve.

Over the past forty years, a series of OPEC orchestrated oil shocks wreaked havoc on the global economy. "These rounds of price gouging coincided with the Yom Kipper War in 1973, the Iranian Revolution in 1979, and the Gulf War in 1991. The latest oil shock followed the attack on the United States on 9-11 in 2001 and the subsequent wars in Afghanistan and Iraq" (Craig, 2011, p. 47).

OPEC's illegal business practices "include not only breach of contract involving asset expropriation but also restraint of trade involving price fixing. Such are the weapons of economic warfare in the Islamic Jihad" (ibid). In a more perfect world, the global market would be free and the playing field would be level. But, as it now exists, capitalist firms, private oil companies, are forced to compete with socialist governments, national oil companies (NOCs), some of which are Muslim states sponsoring terrorism. 
Petroleum importing countries need to pool their purchasing power in order to avoid continual price gouging and intermittent supply shocks. "India has expressed interest in ... the creation of a consortium of Asian consuming nations ... as an alternative to present marketing arrangements" (Vickery, p. 175). The US should not only support this effort it should also support the creation of a consortium of oil consuming nations, an Organization of Petroleum Importing Countries (OPIC), to offset the power of the Organization of Petroleum Exporting Countries (OPEC).

The existing "forum where consumer countries deliberate ... is the IEA (International Energy Agency) ... and India is not a member" (Schaffer, 2009, p. 59). Nor is India a member of the parent organization, the Organization for Economic Cooperation and Development (OECD) but "the United States has ... suggested that India should seriously consider ... membership" (Schaffer, 2009, p. 193).

\subsection{Electrical Gridlock}

The US has had some problems with its gird including the bankruptcy of Enron in 2001 and the recent brownouts and rolling blackouts in California. But India's energy sector is in crisis and collectivism is, as usual, the problem. Although India "has the world's fifth-largest coal reserves ... coal is dug up by a state-monopolist that has failed to boost output ... (and) power is distributed ... by publically owned grid companies that are often bankrupt" (Future is Black, 2012).

"More than half of India's power-generation ... is coal-based ... (but) Coal India Ltd., the world's biggest coal producer, is unable to produce enough owing to delays in getting environmental clearances for mining ... Meanwhile, government giveaways in the form of free electricity to farmers and a reluctance among politicians to raise power tariffs ... to ... cover costs have drained ... the largely state-run electricity-distribution companies, leaving them with mounting debt" (Chaturvedi \& Choudhury, 2012).

"Coal India ... is riddled with trade unionism and gangs who steal coal ... (and) employees (who) collude ... to steal ... fuel ... (while) state electricity boards operate the grid, usually badly ... (and) lose about a third of the power they buy through theft or inefficient kit, and ... another third ... to rural customers who pay subsidized prices or get it free" (Future is Black, 2012).

"The State Electric Boards (SEBs) that run India's electric system have become a byword for fiscal red ink, owing largely to poor bill collection and to the persistent practice by state politicians of offering free electricity to farmers" (Schaffer, 2009, p. 47). "Most local distribution firms are state-owned and all but bankrupt, as politicians insist that tariffs stay low and that big swathes of the population, including farmers, get free power ... (and as) many Indians get away with simply stealing it" (An Area of Darkness, 2012).

The system is not only broke it is also broken. On July 31, 2012, "India's energy crisis cascaded over half the country ... when three of its regional grids collapsed, leaving 620 million people without ... electricity in one of the world's biggest-ever blackouts ... (raising) serious concerns about India's outdated infrastructure" (Nessman, 2012). "But the deeper problem is organizational: a wretched public coal monopoly gets too little of its product distributed by the state-run railways to (mostly) state-run power stations" (Aim Higher, 2012).

In other words, this is not a case of market failure. It is yet another example of government failure on a grand scale. Once again, the emphasis was placed on command and control as opposed to supply and demand. Politicians and bureaucrats did the pricing and rationing instead of producers and consumers. And "the electrical blackouts in July were caused by states ignoring national limits on power use" (Silence of the Bollygarchs, 2012).

\section{The Green Revolution}

Agriculture is important in both the United States and India. In the US, there were 19.27 million hectares of wheat under cultivation in 2010-11 compared to 28.46 in India. In the US, the yield was 3.12 metric tons per hectare compared to 2.84 in India. And, in the US, wheat production was 60.06 million metric tons compared to 80.80 in India (USDA, 2012). But there is a striking contrast between the US and India in terms of demographics.

On the one hand, India "remains predominantly rural: over $600 \mathrm{~m}$ out of 1.24 billion Indians rely directly on farming" or about $48 \%$ (Monsoon, or Later, 2012). On the other hand, "there are over 285,000,000 people living in the United States. Of that population, less than $1 \%$ claim farming as an occupation (and about $2 \%$ actually live on farms). There are only about 960,000 persons claiming farming as their principal occupation and a similar number of farmers claiming some other principal occupation. The number of farms in the U.S. stands at about two million" (EPA, 2012). US wheat farmers like other US farmers are obviously more productive than their counterparts in India. And this has been the case for many years. 
The US “Agricultural Trade ... Development and Assistance Act of $1954 \ldots$ Public Law 480 of the $83^{\text {rd }}$ Congress ... was signed into law by President Dwight D. Eisenhower ... President John F. Kennedy renamed the initiative the 'Food for Peace Program' ... in 1961 ... (and) by 1965, PL 480 had become the largest single US international aid program and India had become the largest single recipient country" (Vickery, 2011, p. 210). "There were times, such as the poor crop years of the mid-1960s, when US assistance was critical to averting famine" across the subcontinent (Schaffer, 2009, p. 28).

"The crucial year was $1965 \ldots$ the monsoon failed ... Indian grain production plunged ... Indian farmers and the public clamored for assistance ... but ... President Johnson ... could see that the upward spiral of assistance to India was becoming unsustainable ... he wanted a plan for India to develop its own 'food security,' its ability to feed itself ... in exchange for massive food aid ... in effect, to implement the green revolution" (Vickery, 2011, p. 215).

The subsequent "agreement said plainly that 'farmers will be given credit regardless of where they buy their fertilizer' ... (and) a minister of the Government of India was committing his government to certain levels of expenditures with regard to agriculture, even if this required cutbacks in other programs" (ibid, p. 217). Thus India was pressured into joining a free market and into realigning its expenditures from the demand side to the supply side, i.e. from individual entitlements to farm subsidies. As a result, "by 1972, India had nearly doubled its harvest of wheat compared with 1968" (ibid, p. 219).

This "first green revolution was in large part a product of assistance provided from essentially US sources to India" (ibid, p. 238). But, as usual, no good deed went unpunished. "When the Johnson administration mounted a massive food aid operation to help alleviate the threat of famine ... it earned Americans no gratitude from India, which was then tilting rapidly into the Soviet foreign policy orbit" (Sieff, 2009, p. 30). The new Prime Minister, Indira Gandhi, "was not pleased by Johnson's pressure tactics for reforming the Indian agricultural system ... (so she) began to criticize the US on other ... fronts, including its conduct of the Vietnam War ... (and) in 1972, Gandhi halted Indian participation in the PL 480 program" (Vickery, 2011, p. 218-219).

Now, fifty some years later, there is talk of a second green revolution as India struggles to feed its ballooning population once again. But "stories of dreadful corruption" and "signs of apparent ingratitude" tend to discourage foreign donors (Last Mile, 2012). There are also other roadblocks to progress.

1) "Electricity is virtually free for farmers in some Indian states ... (and) these subsidies ... have led to the overexploitation of groundwater" (Vickery, 2011, p. 233). This illustrates India's longstanding reluctance to embrace free markets and to enforce property rights including not only mineral rights but also water rights.

2) Due to "increasing salinity ... the amount of land than can sustain agricultural production seems to be shrinking" (ibid, p. 234). Poor stewardship of the land is a direct result of communal policies that have led to a whole host of serious problems.

3) "It has been the official policy to limit the size of landholdings and redistribute land above ceiling limitations ... (and) the smaller landholdings become, the more difficult it is to apply ... modern farming techniques" (ibid, p. 234). This accounts for much of India's agricultural inefficiency.

4) To make matter even worse, "farmers often have not been given title to land ... under programs for land reform" (ibid, p, 235). Thus they have little incentive to either conserve or invest. This is yet another tragedy of the commons and communism that can be rectified only by the institution and protection of property rights.

India should look to the United States as a role model but it should not expect the US to provide free food. Another massive aid program would not only fuel population growth it would also retard essential reform. India's farms are too small and too labor intensive. An agrarian revolution will therefore require an industrial revolution including a mass migration of people from rural to urban areas. And that is indeed the trend.

"Within two decades India will probably have six cities considerably bigger than New York, each with at least 10m people" (Aim Higher, 2012, p. 13). But government is dragging its feet in terms of utilities and infrastructure, e.g. water, sewer, power, and roads. And "putting off urbanization can also mean postponing prosperity ... When farmers leave the land to work in factories, call centers or almost anywhere else, their incomes and consumption almost always go up" (ibid).

\section{Public Education}

In India, "the public education system is mired in politics and inefficiency ... (with) demand for caste-based quotas for more than half of the available seats in public institutions" (Wadhwa, Gereffi, Rissing, and Ong, 2007, p. 75). And, in the US, public schools are desegregated through the consolidation of districts and the bussing of 
students resulting in impersonal education and long commutes. The emphasis is on racial quotas instead of quality instruction and quality time.

The Indian and American systems of public education are generally dysfunctional. "In India ... between a quarter and a third of pupils attend private schools ... (and) in cities the proportion is more like $85 \%$... (since) many parents became disenchanted with state-school teachers who failed to show up or taught badly" (Rich Pickings, 2012). In America, parents send their children to private schools if at all possible. Their desperation is evident since they pay tuition for the private education of their own children as well as taxes for the public education of other people's children.

"Finding skilled staff (in India) is next to impossible because local education is "extremely bad"" (Aim Higher, 2012, p. 11). And even those applicants with college degrees are not always qualified. "Education in engineering, for example, supposedly a great Indian strength, is not what it might be ... with not even $3 \%$ (of graduates) ... ready to be taken on by IT firms without additional training" (ibid, p. 12). In the US, engineering graduates are typically well qualified but too few in number.

A voucher system might solve problems for both India and the United States. Government could agree to pay a set amount for each student and more for those studying math or science. Parents could then choose any public school or any private school. And competition between schools would raise educational outcomes significantly and quickly. Such reform would of course be resisted by a majority of teachers and their unions.

\section{Misadministration}

Indian officials still have a long way to go on the road from the $3^{\text {rd }}$ world to the $1^{\text {st }}$."While decrying the colonial British vigorously, they still retain a colonial (and even a feudal) predilection to dominate and patronize not only the ordinary Indian masses, but also their own less fortunate kin and caste members" (Khare, 2002, p. 258). "We have before us the continuing Indian 'sahib culture' ... hundreds of thousands of fiercely self-protective 'big' ... or 'small' ... sahibs ... spewing secularism, criticizing colonialism, castigating casteism, and vociferously and ruthlessly attacking 'recent religious (read Hindu) fascism' ... but paradoxically these governing elites ... survive by making 'deals' with all of the above" (ibid, p. 254-255).

Cronyism appears to have worsened since "the mid-1990s when India began to be governed by coalitions ... (with) each coalition party ... squabbling to get a slice of the cake" (In Vinod We Trust, 2012). "Red tape and corruption, always present, seem to have gotten worse ... inflation is high and stubborn ... (and) every one of these problems involves the state, still huge and crazy after all these years" (Losing its Magic, 2012).

"India has superb private banks but state-controlled banks still account for three-quarters of all loans ... (and) tend to be in poorer shape than their private rivals" (Hold Your Nose, 2012). The Reserve Bank of India is a respected institution but "India's central bank clearly does not have the power and stature of the American 'Fed" (Lijphard, 2007b, p. 26). The RBI "oversees a financial system that is a conduit for funneling savings into government bonds" (Pulling Every Lever, 2012). But "inflation has risen and remains high ... (and) the (central) bank is loth to cut interest rates sharply until the government borrows less" (Unfinished Journey, 2012).

As usual, "the state is borrowing too much, crowding out private firms and keeping inflation high ... (while) graft, confusion and red tape have infuriated domestic businesses and harmed investment" (Farewell to Incredible India, 2012). "Government borrowing crowds the private sector, which has to live with higher interest rates ... (and) because the state is less likely than private business to spend the cash on investment, it does less to boost the economy's potential" (Pulling Every Lever, 2012). Not only has "foreign direct investment dropped ... the Indian rupee has recently reached record lows against the dollar" (Wholesale Reform, 2011).

In 2011, "an overdue ... decision to let foreigners invest in (and so improve) the retail sector in India was put one hold just two weeks after it was announced" (Gasping for Breath, 2011). Not only is FDI being stymied, "Indian firms are themselves investing less at home due to red tape, graft and a lack of reforms" (Travelers Checked, 2012). "In the face of slowing growth, high inflation and awful corruption, the government is looking increasingly fossilized" (Must it be a Gandhi, 2011). "Since 1991 the private sector has boomed ... (but the) government ... has fallen out of love with reform" (Tales of the Unexpected, 2012). The pharmaceutical industry is a recent example.

"For more than thirty years the country did not recognize pharmaceutical patents" (Taking Pains, 2012). A new system was established in 2005. But foreign firms are accused of "ever-greening" and refused patent protection even when existing drugs are significantly improved. And, if prices are deemed to be "not reasonably affordable," foreign companies are compelled to grant licenses to domestic manufacturers of generic drugs.

In other words, business is still dancing to a government tune. It is like the hokey-pokey, i.e. you put your right 
foot in, you put your right foot out, you put your right foot in, and you shake it all about. The sing-along varies from state to state and from city to city. But, in essence, it remains the same old song and dance. Kick-backs and red tape continue to empty the pockets and tie the hands of India's entrepreneurs.

Misadministration is a serious problem throughout India. It is hard to find an exemplar of best practices. The city of Bangalore is much touted as a hub for information technology but with respect to e-governance "India is lagging behind not only the developed countries in the region but also many other countries" (Farooquie, 2011, p. 11). Officialdom is unresponsive because the ship of state is firmly anchored in the past.

In 1911, The British "King George declared Delhi again to be India's capital, as it had been under Mughal rulers, relegating Calcutta (now Kolkata) to a mere trading entrepot" and today "Dilliwallahs are more than twice as rich as the average Indian" even though the city suffers from "dreadful air pollution, a lack of clean water and vast, sprawling slums" (More than Pomp and Frolics, 2011). "The World Bank says bad sanitation and water pollution cost India 6\% of national income" (Shoots, Greens and Leaves, 2012). It is time for the government to clean up its act. A pristine environment and a vibrant economy are not mutually exclusive (Craig, 2011, p. 48).

Poor governance is unfortunately the rule rather than the exception. The city of Mumbai (or Bombay) has "'some of the most extreme land-use restrictions in the developing world' designed to deter new migrants but which have backfired" (Minimum City, 2012). Transportation links are poor, so people who work in the city live in the city. Since housing is scarce, "the share of people in slums has risen to perhaps $60 \%$, compared with $20 \%$ in ... Delhi" (Minimum City, 2012). New railroads and highways would enable workers to commute. But "the balance sheets of many Indian infrastructure firms are as potholed as the roads they resurface ... (and) new business has all but ground to a halt ... partly ... because officials are scared of being accused of graft" (Infrastruggles, 2011).

India's problems are painfully evident yet typically ignored. The problems associated with mineral rights and broadcast rights are illustrative. "The idea that mining licenses and mobile spectrum should be auctioned, not given to government friends, is widely held" but officials are "not making decisions" for fear they will end up in jail (In Vinod We Trust, 2012).

"Bears in Mumbai, India's financial capital, worry that GDP growth might slip ... (with) the gumming up of the bureaucracy due to a wave of graft allegations" (Case for the Defense, 2011). At present, "officials don't know whether to turn a blind eye or blow their whistles" (Megahurts, 2012). Some "local firms wallow in cash, hungry for a chance to invest, but they need predictability about policy and decision-making ... (and) foreign firms ... also hold back, unsure of the politics" (Booted Upstairs, 2012). Fear has led to paralysis.

The government's inattention to important issues is in part attributable its fixation on identity politics. But mostly it is the result of its preference for socialism over capitalism. "By international standards, India is still a heavily administered and relatively closed market" (Schaffer, 2009, p. 22). "Tariffs are still high compared to the global average" (ibid, p. 23). And the government's inept and misguided policies contribute to persistently high unemployment.

"Even after 25 years of accelerated growth, India remains a low income country in which about one-fourth of the population live(s) on less than one dollar a day" (ibid, p. 20). Perhaps even "one-third ... lives on less than a US dollar a day" (Shieff, 2009, p. 121). By any measure, absolute poverty continues to be a serious problem. "India ... remains an intolerable mess of corruption, inequality, and squalor, and yet, overall it is an optimistic place" (Mixed Blessings, 2012) albeit tinged with a degree of fatalism.

"The core of the internal problem is often summed up as 'governance' ... first, politicians (netas) who do not rule ... failed to carry out profound reform, passed no significant legislation, and ... (are) mired in sleaze ... Now add unhelpful babus, bureaucrats working in an ossified system ... (with) too much of ... the economy ... run - or rather - held back, by officials" (Aim Higher, 2012, p. 3). Misadministration, including cronyism and corruption, is much more serious in India than in the US. But both countries would benefit from improved governance especially in terms of less complex and more consistent regulation.

\section{Dependency Theory}

A convenient scapegoat for domestic problems is foreign trade whether services or goods, imports or exports. Xenophobia is another facet of socialist ideology with its overarching emphasis on victimhood, e.g. class war, race war, the battle of the sexes, etc. "Slavery, colonialism, imperialism, capitalism, and dependency are commonly viewed by Marxists and neo-Marxists as part and parcel of the same theoretical landscape" (Craig, 1995, p. 173). And leftist propaganda is now as pronounced and persistent in the US as it is in India. The disastrous consequences of socialist policies are today economically evident not only on the subcontinent but 
also in America.

Dependency theory is centered upon economic power differentials between nations. It focuses on exploitation of the weak in the undeveloped or underdeveloped periphery by the strong in the developed center. But theories may be either true or false. And, around the world and across the years, trade has proven to be mutually beneficial. Indeed, "the benefits of dependence are probably most evident in terms of supply and demand ... and comparative advantage ... (since) dependency is seldom if ever a zero sum game" (ibid, p. 269). This is as true for services in the labor market as it is for goods in any other market. By definition, free travel and trade are voluntary and therefore desirable.

Personal freedom and prosperity are universal and timeless values, unlimited in their geographic and historic scope. "One might expect that the differences in cultures, institutional environments, and market conditions of the United States and India would result in different ... behaviors among entrepreneurs ... (but) Indian and US entrepreneurs are more alike than they are different" (Stewart, May, \& Kalia, 2008, p. 97). And business is business whether it is conducted at home or abroad.

The situation is admittedly much less salubrious for the "estimated 4 million to 5 million Indian expatriates ... in the (Persian) Gulf ... the second largest source of remittances to India after North America" (Schaffer, 2009, p. 159). Foreign workers in the Middle East are not exactly in living in paradise. Yet reflexive anti-Americanism is still the rage in India and elsewhere. For some reason, perhaps envy, "the US is routinely blamed for the woes of the world" (Craig, 2011, p. 43).

All across India, "anti-American attitudes among politicians and bureaucrats in the $1970 \mathrm{~s}$... created a negative research climate ... (but since) the 1980s ... American academic enterprises have prospered ... focusing on ... topics such as ... the dalit experience and communalism" (Barrier, 2002, p. 96). There was a convergence of anti-American opinion due to the growth of the radical left in US academia and media. The clamor in the US now equals the clamor in India. Professors and journalists demand preferential treatment for people who are less than white and perpetual subsidy for people who are less than rich. Politicians and bureaucrats respond with color lines and income brackets that are arbitrary and divisive.

The self-professed champions of the working class demand protection from cheap foreign labor on the one hand and complain about the brain drain on the other while ignoring their own slogan "Workers of the World Unite" (Marx \& Engels, 1848). In the US, one hears protests over the jobs lost due to outsourcing whereas in India one hears laments over the talent lost due to emigration. In other words, socialists are now implying that the negative effects of dependency theory apply to the $1^{\text {st }}$ world as well as to the $3^{\text {rd }}$. This of course compounds the lie.

"Any trend toward protectionism in the First World poses as much of a threat to free trade and economic efficiency as does any trend toward isolationism in the Third World (or Second). And, what is true for raw materials and manufactured goods is likewise true for people and money. Restrictive importation and immigration policies, so common in the First World, are as much of a hindrance to freedom and prosperity as are restrictive investment and repatriation policies, so common in the Third World (or Second) (Craig, 1995, p. 282)."

As indicated in its preamble, the Constitution of the United States was established to "promote the general welfare" not Affirmative Action for groups nor monetary entitlements for individuals. And although times have changed, "the blessings of liberty" including both free trade and travel are still hard to deny. As stated in the Commerce Clause (Article I, Section 8), "The Congress shall have power ... to regulate commerce with foreign nations and among the several states and ... to establish an (sic) uniform rule of naturalization" (Constitution of the United States, 1787). The founders recognized that trade and travel between nations are as important as trade and travel within nations.

Instead of socialism or centralized command and control, capitalism or "centralized decontrol is the obvious choice when it comes to promoting both peace and prosperity. Free trade depends on a common market just as free travel depends on a common border or at least a porous one. The main tragedy of communism or fascism, either extreme of socialism, is poverty" in addition to conflict (Craig, 2010, p. 416). Autarky does not promote domestic development nor does it enhance international relations.

"The intellectual tradition that supports the notion that the welfare of both countries would increase through cooperation goes back to Adam Smith and (David) Ricardo ... (and) in the theory of welfare economics (a misleading appellation if there ever was one), such mutually agreeable contacts between countries are said to be efficient because these contracts have the potential to improve the welfare of at least one country, without hurting the other ... (and) are said to satisfy the (Vilfredo) Pareto criterion ... (but) countries often undertake policies to 
punish each other, which in turn, lead to a reduction in welfare for all " (Gajanan \& Radhakrishnan, 2002, p. 106).

All countries depend on something. Some depend on socialism including regulation, subsidy, and isolation. Others depend on capitalism including competition, specialization, and trade. Some rely on the government owned corporation (GOC), government sponsored enterprise (GSE), and state owned enterprise (SOE). Others rely on the multi-national corporation (MNC), trans-national corporation (TNC), multi-national enterprise (MNE). Some depend upon centralization, government, and taxes. Others depend on individualism, business, and profits. It is a philosophical difference with dramatic consequences both at home and abroad. Dependency theory as conjured in the ivory tower of Marxist dogma is just another name for mercantilism or protectionism. India and the United States should avoid all such "beggar thy neighbor" policies.

\section{Affirmative Action}

Both the United States and India have massive Affirmative Action programs: for minorities and women in the US; and for Scheduled Castes, Scheduled Tribes, and Other Backward Classes in India. After centuries of Islamic subjugation, "the institution of caste, independent of the government and with social ostracism as its most severe punishment, was a powerful factor in the survival of Hinduism ... (and) the Hindu, living under an alien political order imposed from above, retained his cultural individuality largely through his caste" (Basham, 2004, p. 152).

"Hinduism, relying for its strength mainly on independent brahmans and ascetics and on domestic ceremonies, suffered from the Muslim invasion but was not seriously weakened by it ... (whereas) Buddhism ... could not stand up to the change ... (and) survivors fled to the mountains of Nepal and Tibet" (ibid, p. 268). But, in 1949, the Chinese occupied Tibet. And, in 1959, the $14^{\text {th }}$ Dalai Lama escaped to India. Then, in 2008, Maoists took over the government of Nepal. Some groups seem to have no luck except bad luck.

"India's ancient culture did not perish before the onslaughts of the Muslims, as did that of Persia ... (but some) Hindus began to learn Persian, the official language of their Muslim rulers, and Persian words found their way into the vernaculars" (ibid, 481). "In the last decades of the British Raj (or reign) more than 90 percent of the population in south India spoke languages in the Dravidian family, all of which ... were unintelligible" to speakers of Hindi, the major language of the north; and, "nationalists in the south ... argued that traditional Dravidian culture had been more socially egalitarian than the version of Hinduism ... imposed upon Dravidians by northern Brahmins" from the top of the Hindu caste system (Stepan, 2007, p. 242).

Regional and linguistic cleavages were sharpened by cultural differences. And, to make matters more divisive, "the two intermediate Hindu castes, the Kshatriyas and the Vaishyas, were virtually not present in south India and south Indians belonged, therefore, to either to the lowest category of caste ... the Shudras or were untouchables" (ibid, 242). These so-called untouchables were below "the four classes of ... Hindu society" and their very touch "was considered ritually polluting on account of the professions pursued by them, which were considered unclean" (Sharma, 2005, p. 180).

"Only in the last fifty years has the caste system shown real signs of breaking down, thanks to the many inventions of the West not designed for use in a society divided into watertight compartments, the spread of Western education, growing national sentiment, and the intensive propaganda of enlightened leaders" (Basham, 2004, p. 152). But "India still remains a very casteist and patriarchal society; asymmetries of power and resources are persistent and cumulative" (deSouza, 2007, p. 274). "India's richest state, Gujarat, has a per capita GDP 4.7 times that of the poorest state, Bihar" (Schaffer, 2009, p. 26). And "two-fifths of Indian children still suffer malnutrition" (Last Mile, 2012).

There are however "signs of a shift away from identity politics" and, in recent elections in "five states, female voters substantially outnumbered males" (Welcome Slap in the face, 2012). "In the exercise of building democracy in India ... various interesting experiments are underway in the different states of the union ... (but) what is common to all state experiments on decentralization is the desire to redress the development deficit that plagues independent India" (deSouza, 2007, 278-279).

"The debate (in India) echoes the debate current in the USA but ... Affirmative Action in the USA is closely tied to the short history of slavery ... (whereas) Affirmative Action in India ... (is) closely tied to the long history of Untouchability ... a 2000 year long history ... (versus) a history of 200 years" roughly speaking (Sharma, 2005, p. 11). In both cases, the time periods are actually much longer. Segregation in the US is about five hundred years old and dates back to 1526 and the first African slaves in America in the Spanish colony of San Miguel Gualdape in present day South Carolina (Spillane, 1913). "The caste system in India is over three thousand years 
old and dates ... back to the ancient Hindu scriptures ... (as) the Vedic term for caste is 'Varna' which means color" (Boston and Nair-Reichert, 2003, p. 8).

The English terms for mixed-race are borrowed from the Spanish and all based upon color. Mulatto means half white (Caucasian or European) and half black (Negro or African), quadroon means a quarter white, and octoroon means an eighth white. But hypo-descent is the norm, the social practice which assigns children of mixed parentage, interracial marriage, or miscegenation to the subordinate group.

In the US, the mixing of races is fairly common now. And, in India, "marriages that cross caste boundaries are more widespread" than in the past (ibid, p. 9). But racial harmony is still problematic in both countries. Segregation in the US is similar to untouchability in India in as much as both social systems are visibly drawn along the lines of color. Likewise, "the challenges to implementing affirmative action confronting both countries are remarkably similar" (ibid, p. 3). The nomenclature is however slightly different. America's racial preference program is referred to as Affirmative Action whereas "India's affirmative action policies are referred to as compensatory discrimination" (ibid, p.8). But, in either case, one is left to wonder whether "the polarization is worth the preference" (Rosenbloom, 1998, p. 63).

Slavery in the US ended after the Civil War in the $19^{\text {th }}$ century. It is now the $21^{\text {st }}$ century. And there is less discrimination in American than ever before. Indeed, a person of color, Barrack Obama, is the freely elected President of the United States. One must therefore question the need for further Affirmative Action. Compensatory discrimination for past injustice is ideal but impractical. It is impossible to "make whole" those who suffered and died. It is of course possible to punish the living for the sins of the dead, one generation for the sins of another. But this is as unwise as using taxes and subsidies to punish success and reward failure.

In any case, group punishment is unwarranted since the innocent are punished along with the guilty. There is variation not only between groups but also between members. Government should not penalize those who do not discriminate. The socialist champions of multiculturalism and diversity are also the hypocritical champions of regimentation and collectivization. But the ends cannot justify the means. And idealism cannot justify oppression.

Equal opportunity depends upon equal protection not preferences. Immigrants come to the United States from all over the world. Most succeed without special assistance from the government. Indeed, "the per capita income of Indian Americans exceeds that of every other group in the country (including whites) except Japanese Americans" (Hathaway, 2001, p. 24). And successful groups like the Japanese have overcome serious obstacles including internment in concentration camps during World War II. So one is tempted to ask why blacks or any other group should receive preferential treatment at the expense of the general public. A preference can easily be interpreted as "a 'civil wrong' instead of a civil right" (Tummala, 1999, p. 505).

"Those who argue against affirmative action policies maintain that ... there should be no discrimination whatsoever based on sex, race, caste, class, etc." (Sharma, 2005, p. 21). In India, "affirmative actions instead of lowering caste barriers have made caste more of an issue ... (with) the perverse result of strengthening ... class identity ... leading to greater social stratification ... (and) that reservation policies have placed ... people ... not by merit ... and hence ... incompetent to do their job" (Boston and Nair-Reichert, 2003, p. 11).

The libertarian opponents of AA in the US "argue that encouraging blacks to 'play the race card' fosters a sense of grievance among blacks of all classes" (Tummala, 1999, p. 505). This is especially likely among upper class blacks since racial preferences lead people to question their credentials. But identity politics remains a popular pastime even though it is divisive inwardly as well as outwardly. And the socialist proponents of AA in the US take themselves very seriously. They are so easily offended that joking about race, sex, or sexual practice is no longer a laughing matter. In fact, such humor is now a crime classified as hate speech instead of free speech.

In India, "blocks of voters are often defined by caste or religion, so politicians find rows like these useful ... as a pretext for presenting themselves as stout defenders of ... the supposedly offended victims" (Badly Drawn, 2012). In the US, politicians shamelessly cater to constituents based on ethnicity, gender, or sexual orientation. Difficult questions about important issues involving the economy, the environment, and national security are thereby avoided.

Those who oppose reverse discrimination point to "the contradiction ... between a staunch commitment to the equality principle, which is the watchword of democracy, and the special treatment of minorities" (Tummala, 1999, p. 497). "The formal guarantee of 'equal protection' in both (the Indian and American) constitutions is, to the critic of reservations or affirmative action, transgressed ... (since) justice no longer wears a blindfold ... and in both countries too there is controversy over ... whether it would not have been better if ... circumstances had 
been addressed by common policies for all the poor ... (and) illiterate" (Glazer, 2007, p. 161).

At least, in India, "the court ordered the government to adopt an 'economic means test' to ensure that the more advanced members of the backward classes did not profit from reservation schemes" (Boston and Nair-Reichert, 2003, p. 10). And, in the United States, some judges and justices believe "in racial neutrality as furthering equal protection" and detest "racial paternalism" while others do not support "a proactive judiciary, believing that social policy is the purview of the legislator" and still others do "not believe in group rights" (Tummala, 1999, p. 502). Instead, they believe that "group rights ... should not ever, violate the individual's rights" (Linz, Stepan, \& Yadav, p. 59). But these are typically minority opinions. Most jurists still favor social engineering.

Fortunately, discrimination is not the problem it once was in either India or the US. Kocheril Raman Narayanan became the first untouchable President of India in 1997 and Barrack Hussein Obama became the first black President of the United States in 2008. Racial "tensions ... have subsided ... (even though) the acceptance of group rights" in India contrasts with "the emphasis on individual rights in the USA" (Sharma, 2005, p. 10-11) and even though the expansion of affirmative action policies in India contrasts with the contraction of such policies in the United States (ibid, p. 18). There are also religious differences. The Christian influence favoring desegregation in the US contrasts sharply with the Hindu influence favoring separatism in India.

"Hinduism consists of four castes ... the Vedic term for caste is 'Varna' which means color ... the highest Varna is Brahman ... priests and educated people ... the next ... is Kshatria ... rulers and aristocrats ... after them are ... Vaisias ... landlords and businessmen ... last ... are the Shudras ... the peasants and working class ... below the caste hierarchy are the outcasts ... considered untouchable by the four castes" (Boston and Nair-Reichert, 2003, p. 8). Untouchables are also known by an older name, Harijans, and by a newer name, Dalits (Glazer, 2007, p. 149). The Socially and Educationally Backward Classes (SEBC) consist not only of scheduled classes "listed in a schedule of the Indian constitution" but also of scheduled tribes "listed in a schedule of the Indian constitution" (Sharma, 2005, p. 179). "The scheduled tribes are also called Adivasi (meaning aboriginals)" (Boston and Nair-Reichert, 2003, p. 8).

"The brief of the National Commission for Scheduled Classes and Scheduled Tribes (NCSCST) ... covers the range of groups that in India are called 'tribal' ... (and) some tribal groups are parallel to American Indian tribes ... living on land ... reserved to them by law ... (but) they are ... not a caste within Indian society, and are not divided within by caste ... (these) tribal groups ... form about 7 percent of the Indian population ... (whereas) American Indians are less than 1 percent of the American population" (Glazer, 2007, p. 146).In other words, there are native Indians just as there are native Americans or American-Indians as distinguished from Indian-Americans, plain Americans, and plain Indians (but not plains Indians).

On the sub-continent, there are Marxist groups who claim to speak "on behalf of tribal forest dwellers" including "India's Maoists ... the Naxals" who terrorize "the "red corridor' of ... central India" although some, "keener on extortion than left-wing ideology, are evolving into criminal gangs taking pay-offs from mining firms" (Blood in the Corridor, 2012). "The Communist Party of India (Maoist) ... (or) Naxalites ... last year killed 1,180 people, more than all other insurgent and terrorist groups combined" (Red Retreat, 2011).

In the US, there are radical organizations such as the American Indian Movement (AIM) but most native-Americans are understandably more interested in obtaining their share of casino profits from the gambling done on reservations. And, unlike the federal government, many tribal governments are making it harder for people of lesser blood to be counted as Indians. "Indian casinos are now operated in 28 states by 233 of the nation's 562 tribes ... (and) the total number of Indian casinos is approaching 500" (Indian Casinos Supersite, 2012). In this and many other ways, the tribes of America are doing much better than the tribes of India.

"Both India and the US have special rules in their electoral systems to provide for the representation of specified minorities": In India, there are "reserved seats" for scheduled classes (SCs) or untouchables; and, in the US, there is "affirmative gerrymandering" for African-Americans (Lijphart, 2007b, p. 39). Untouchables in India "like blacks in the US, despite a substantial range of governmental programs to improve their condition ... bear ... poorer economic conditions, poorer education, (and) poorer conditions of life generally" (Glazer, 2007, p. 146). Blacks in the US are however doing much better than untouchables in India. In fact, they are far better off in the United States than they are anywhere else including Africa.

"As is typical of so many affirmative action programs intended to be in force for a (limited) number of years ... reservations for the SCs ... (have) been renewed regularly every ten years" (ibid, 155). These reservations include "seats in the legislature, public employment and educational institutions" (Sharma, 2005, p. 179). Nevertheless, proponents claim that "affirmative action policies are intended to be ... temporary" (ibid, p. 29). 
"After the collapse of the Soviet Union, "major neo-liberal reforms were put into place in India ... but the reforms of 1991-93 left the labor market untouched" (Perry, 2006, p. 16-17). And social engineering in the form of Affirmative Action is still a drag on the economy. With India's "archaic labor laws ... nobody in in their right mind is going to set up a plant employing 10,000 people" (Masala Mittelstand, 2012).

Neo-liberal or laissez faire reforms would involve "reduced government regulation of labor markets ... greater employer choice in hiring and firing workers $\ldots$ and ... reduced legislative and/or administrative support for unions" (Perry, 2006, p. 9). Reasonable reforms would also involve the elimination of compensatory discrimination including all forms of reverse racism and reverse sexism. That is the trend in the US but not in India.

One explanation is this: "Generation as a sub-culture can moderate the national cultural orientation" and both India and the United States have experienced "intergenerational transition in individualism/collectivism orientations" (Ghosh \& Chaudhuri, 2009, p. 12, 5). Out-of-phase development in cultural orientations could very well explain the different emphasis on Affirmative Action policies at present.

Demographically speaking, there are three cohorts in India: "conservatives, born between 1947-1969 ... integrators, born between 1970-1984 ... (and) the Y2K generation, born between 1985-1995 (ibid, p. 7-8). And, there are three roughly corresponding groups in the US: "the Baby Boomers, the X Generation (the Baby Busters), and the Y Generation (the Millennials)" but, chronologically speaking, the transitions in India and the US are somewhat out-of-sync since Generation X Americans are "very similar to the Generation Y2K Indians" (ibid, p. 9). Or, to put it another way, the past of one country can be the present (or the future) of another.

\section{The War on Terror}

Both the United States and India face the threat of Islamic terror. The homelands of both countries are targets by default since the American population is $85 \%$ Christian and the Indian population is $82 \%$ Hindu (Christie, Kwon, Stoberl, \& Baumhart, 2003, p. 270). But Muslims comprise under 1 percent of the population in the US and over 15 percent in India. "Radical Islam ... poses an existential threat to India ... given its large Muslim population ... the third largest in the world" (Mohan, 2006, p. 25). Internationally, the US and India are natural allies in the War on Terror whether it be a forward defense vis-à-vis Afghanistan or a proximate defense vis-à-vis Pakistan.

Europeans faced the Mohammedan threat from its inception. By $711 \mathrm{AD}$, the Islamic Empire encompassed not only the old Persian Empire and North Africa but also northern parts of the old Roman Empire including France, Portugal, and Spain. Charles Martel stopped the advance of the Saracens at the Battle of Tours in 732. But it was not until 1492 that the Moors were finally driven out of the Iberian peninsula by the forces of Ferdinand and Isabella. That was of course the same year that Columbus discovered the New World he thought was India.

In 1814, Americans responded to attacks by Barbary pirates off the coast of Libya. This naval battle was commemorated in the lyrics of the Marine Corp Hymn, i.e. "the Shores of Tripoli." Two centuries later, piracy remains a common tactic of the Islamic Jihad. It includes not only the high-jacking of ships, especially tankers carrying oil, but also commercial aircraft. In 1988, 259 passengers and another 11 people on the ground in Scotland were killed in the bombing of Pan Am Flight 103. And Americans continue to travel at their peril.

American embassies have been under siege throughout the world since the year-long hostage crisis in Iran from 1979 to 1980. In 1983, a suicide bomber killed 63 people at the US Embassy in Lebanon. In 1998, the embassies in Tanzania and Kenya were bombed killing 223 people and injuring 4000. In 2008, 19 people died and 16 were injured when gunmen attacked the US Embassy in Yemen. There were other attacks as well. The most recent occurred in Libya in 2012 (Shwayder, 2012).

No American can forget the morning of September 11, 2001. A group of nineteen terrorists (including fifteen Saudi nationals) hijacked four US passenger jets, flew two into the Twin Towers of the World Trade Center in New York, one into the Pentagon in Virginia, and another into the ground in rural Pennsylvania killing almost three thousand people in all (A\&E Television Networks, 2012).

Likewise, no Indian can forget the evening of November 26, 2008. "A group of ten Pakistani nationals disembarked from a rubber landing craft in the vicinity of Mumbai's Gateway to India (built during the British Raj) and attacked the Taj Mahal and Oberoi hotels, the Leopold Café, and other targets ... (leaving) 169 people ... killed and more than 400 wounded" (Vickery, 2011, p. 124). And the attack in Mumbai (formerly Bombay) was just one of many.

"With over one-hundred thousand casualties, terrorism has taken more lives in India than any other country" (Bhoumik, 2005, p. 329). And the Jihad impacts not only Christians and Hindus but also animists. Assam is one 
of the Indian states on the eastern side of Bangladesh. There "a fight ... between indigenous Bodo tribesman (pronounced Boro) and Bengali-speakers ... illegal immigrants from Bangladesh ... mostly Muslim ... has been going on for decades" (Neglected Crisis, 2012).

"The contemporary ethno-religious antipathies between Hindus and Muslims that led to the separate states of India and Pakistan ... had their origins in the Muslim invasions ... around 1000 A.D. ... (leading) to a ... population that ... was 75 percent Hindu and 25 percent Muslim ... (and) the disparity between Muslim political dominance and Hindu demographic dominance" (Gould, 2002, p. 168-9).

Through "the ages India has been the target for invasions" including non-Islamic Persians, Greeks, Bactrians, Parthians, Scythians, Kushanas, Huns and then Muslims including Arabs, Turks, and Islamic Persians (Invasion, 2012). In other words, "Islamic invaders were not the first ... in earlier times, the (non-Islamic) Iranians, the Greeks, (the Bactrians,) the Parthians, the Scythians, the Kushanas, and the Hunas ... also invaded India ... but ... these (early) foreigners (were) fully assimilated" (Goel, 1994, p. 104). "The indigenous population ... found it well-nigh impossible to co-exist peacefully with the Muslims" (ibid, p. 105). So, over time, the vast land of India was dismembered losing first Afghanistan then Pakistan and Bangladesh. And, today, jihadists fueled with petro-dollars dream of taking over what is left.

There have been "recurrent Hindu-Muslim riots ... since partition" in 1947 and even now "the most serious problem in India is that of the Muslims" (Glazer, 2007, p. 182-3). "The partition of the South Asian subcontinent along religious lines (first into India and Pakistan, in 1947, then into India, Pakistan, and Bangladesh, in 1971) left India with a persistent conflict with Pakistan and an internal Hindu-Muslim divide" (Mohan, 2006, p. 17) as well as intermittent troubles with Bangladesh.

Although "there are very few Hindus left in the former West Pakistan which now bears ... the name of Pakistan ... Hindu refugees still come ... from Bangladesh, the former East Pakistan ... (and) Kashmir ... is the source of continual enmity between India and Pakistan and ... the cause of a number of wars" (Glazer, 2007, p. 184). Today "the disputed status of Kashmir remains the most contentious issue between India and Pakistan" (Sieff, 2009, p. 24). But "the rise of Islamic extremism in Bangladesh" also poses a significant threat (Mohan, 2006, p. 18).

India is not of course alone in the ongoing holy war between Muslims and non-Muslims, mu'mins (believers) and kafirs (non-believers or infidels). The problem of Islamic extremism affects America, Africa, Europe, and Asia (and not just the subcontinent). Both Russia and China are coping with Islamic terrorism. And countries from Myanmar to the Philippines face similar threats to national security. The so-called Arab Spring is simply a resurgence of the caliphate movement in another guise.

The expansion of Mohammedanism should not be taken lightly. "No country where Islam has attained unrivaled power has allowed non-Muslim minorities to survive" unmolested (Goel, 1994, p. 105). "Al-Qaida hopes to convert others to the ultimate jihad by recruiting across borders within the ummah (Islamic community) ... (and) there is little to negotiate ... (since) Al Qaida has elevated terrorism to a strategy, not to secure achievable objectives but rather to pursue a kind of 'clash of civilizations' ... Huntington's theory" (Picco, 2003, p. 16). It is a suicidal attempt to convert the world to Islam. The holy war is having a profound effect but not the one Islamists intended. Terrorism is turning many nations into virtual police states but more so the US than India.

\section{The China Factor}

Although non-state actors play various roles on the world stage, nation-states are still the stars. And now the United States and India must interact not only with the falling star of Russia but also the rising star of China, the newest super-state. The Old Cold War ended with the collapse of the USSR, the Union of Soviet Socialist Republics, the largest land empire in history. But a New Cold War began with the rise of the PRC, the People's Republic of China, the most populous country ever. And the Chinese record with regard to human rights is not exactly stellar.

The Great Leap Forward in 1957 led to the execution of half a million or more civilians in a single year. It also led to the worst famine in the history of the world. Forced collectivization resulted in the starvation of millions of Chinese in the years just prior to 1961 (Harms, 1996). The suffering of the citizenry continued under the Great Proletarian Cultural Revolution from 1966 to 1976 with state sponsored killings and other gruesome methods of social engineering. Red Guards waving copies of Mao's Little Red Book carried out a so-called cultural revolution that "claimed the lives of several million people and inflicted cruel and inhuman treatments on hundreds of million" more (Yongyi, 2012). 
Much is known about Hitler and the Holocaust in Germany under the Nazis, the National Socialist German Workers Party. But most teachers and journalists still ignore the earlier atrocities of Stalin in the Soviet Ukraine and elsewhere in gulags and purges. They also ignore the later atrocities of Mao during the Great Leap Forward and the Cultural Revolution. "Such is the left-wing bias in academia and media" (Craig, 2010, p. 417). It is conservatively estimated that "between 15 million and 25 million people died unnatural deaths during Mao's reign from 1949 until his death in 1976" (Duff-Brown, 1994). Given China's track record in terms of genocide, both the United States and India should tread with caution.

World War II ended with the USSR occupying the northern part of Korea and the US occupying the southern part. In 1950, South Korea was invaded first by North Korea and then by China. The so-called Korean War was essentially a proxy war between communist and non-communist forces, mainly Chinese and American. The war ended in 1953 in a stalemate with a demilitarized zone (DMZ) between North Korea (the Democratic People's Republic of Korea) and South Korea (the Republic of Korea). After more than fifty years, the differences between the two countries are striking. People in the north are impoverished and persecuted whereas people in the south are prosperous and free. Similar results were evident in East and West Germany after World War II. Such are the differences between communism and capitalism.

"In $1962 \ldots$ the Chinese Red Army whipped Indian forces in a war amid the high glaciers of the Himalayas ... and the memory of that defeat continues to haunt Indian policy makers to this day" (Sieff, 2009, p. 26). "It was the perceived Chinese threat that India cited to justify its nuclear test in 1998. And China still goes out of its way to remind the world that it has not dropped its claim to "south Tibet' in the Indian state of Arunachal Pradesh" (Smoke without Fire, 2012). Today, "Indians worry about possible Chinese plans for an eventual military presence in the Indian Ocean" (Schaffer, 2009, p. 70).

"India's rivalry with China makes it a natural partner with the United States against the day when US and Chinese interests and ambitions will clash" (ibid, p. 11). "For both India and the United States, China's expanding power is the most important development in East Asia" (ibid, p. 139). At present, China is an important trading partner not only for the subcontinent but also for America. And it is possible that China will continue to liberalize following in the footsteps of Hong Kong and Taiwan.

"Despite China's lip service to a ... communist belief system, that ideology has largely been abandoned by policy practitioners" (Kenny, 2012, p. 10-11). China is not however a democracy. And dictatorship could once again result in upheaval at home and/or aggression abroad. The US and India should therefore support all Chinese reforms leading to democracy and capitalism, freedom and free trade.

At present, there are five permanent members of the United Nations Security Council: China, France, the Russian Federation, the United Kingdom, and the United States (UN Security Council, 2012). India is intent upon "obtaining a permanent seat on the United Nations Security Council ... (and) New Delhi expects that Washington will support and assist it in this effort" (Ganguly \& Scobell, 2005, p. 41). The US should by all means advocate a permanent seat at the table for the world's largest democracy.

\section{Nuclear Proliferation}

"India decided not to sign the Non-Proliferation Treaty (NPT) in 1968 ... (and) its 'peaceful nuclear explosion' in $1974 \ldots$ triggered tighter international restrictions on peaceful nuclear commerce" (Schaffer, 2009, p. 89). But "India claims that the non-proliferation regime ... lacks legitimacy ... (describing) the current non-proliferation regime as 'nuclear apartheid' foisted on states too weak and poor" (Sperling, 2002, p. 460). If India gets its way, most if not all countries will strive to become nuclear powers. And, since some countries are "rogue nations" or "failed states," nuclear weapons will fall into the hands of terrorists.

History clearly shows that nuclear proliferation is a slippery slope. "India's ... military nuclear tests in 1998" led to Pakistan's military nuclear tests just three weeks later (Schaffer, 2009, p. 90). It makes no sense for regional powers like India and Pakistan to compete in a nuclear arms race when global powers like the US and Russia are cooperating to disarm. Instead, India and Pakistan should join with the US and Russia in pressuring belligerent countries like Iran and North Korea to become part of the international disarmament process. This would encourage other nations including China to abide by the Non-Proliferation Treaty.

India is beginning to cooperate but recent developments in Pakistan are not promising. "First, no country has such an appalling record as a proliferator ... second, parts of the Pakistani establishment seem to sympathize with militant Islamist movements" and, third, there "is the risk of terrorists breaching Pakistan's defenses ... to get their hands on fissile material or an assembled warhead" (Nuclear Profusion, 2012). Pakistan is on the verge on becoming another rogue nation or failed state. 
"India's history of repeated invasion and subjugation ... manifests itself as a huge standing army and a nuclear deterrent ... (and) the threat has almost always come from the northwest and has usually been Muslim" (Sieff, 2009, p. 11). "The India-Pakistan dispute goes back to the partition of India (in 1947) ... (and) centers on identity ... (1) India ... a multi-ethnic and multi-religious state with a Muslim population as large as Pakistan's ... (2) Pakistan ... a homeland for the Muslims of the subcontinent ... and (3) Kashmir, the one Muslim-majority (Indian) state that did not become part of Pakistan" (Schaffer, 2009, p. 119) not to mention (4) the independence of Bangladesh in 1971.

In 1948, "India and Pakistan ... agreed to a ceasefire and implemented the Line of Control in western Kashmir, leaving most of the state in Indian hands" (Sieff, 2009, p. 24). Then, "in 1965, the Indian Army demonstrated its continuing superiority over Pakistan in a second round of hostilities over Kashmir and, in 1971, it knocked Pakistan out of the ring in the war to liberate East Bengal - soon to be Bangladesh" (ibid, p. 85).

The initial partition of India made East Bengal part of Pakistan. So at first Pakistan was united in terms of its religion, Islam, but split in terms of its territory being both east and west of India. In 1971, "The Pakistani repression of the east Bengal independence movement ... provoked Indian intervention, and the most decisive Indian military victory over Pakistan in the three (or more) wars they ... fought since independence" (ibid, p. 29).

Then "a political insurgency (in Kashmir) which was to disrupt the valley for ... seven years erupted in 1989" (Tremblay, 2002, p. 501). "The main concern of the US was to prevent the escalation of the Kashmir crisis into a general war between India and Pakistan ... (but) the US' neutral stance in the Kashmir dispute was ... questionable ... (since) the US was providing military assistance to Pakistan" (ibid, p. 505, 509). Likewise, "India's adherence to its policy of non-alignment remained a serious obstacle ... (to any settlement in the UN and) the Soviet Union emerged as India's biggest ally in the Security Council” (ibid, p. 508, 514).

The Indian claim of non-alignment vis-à-vis the USSR was in fact no more creditable than the American claim of neutrality vis-à-vis Pakistan. Given the dangers of nuclear proliferation and war, both India and the United States might be well advised to pursue a more straightforward approach to foreign policy. But, as strange as it may seem, "India wants America to preserve its ties to Pakistan, since no one else, certainly not China, would help moderate Pakistani behavior" (Aim Higher, 2012, p. 15).

"The Kargil War between India and Pakistan, waged in the disputed and mountainous Kashmir region in mid-1999, rates as the highest-elevation conflict in air war history ... The clash lasted 74 days and cost more than 1,000 killed on each side" (Lambeth, 2012, p. 118).

Today Pakistan seems intent upon developing the third leg of its nuclear triad, "nuclear armed ships and submarines" in the Indian Ocean (Nuclear Profusion, 2012). The potential threat to commercial shipping in the Arabian Sea is obvious. "India's ... preoccupation with maritime security, the direct consequence of its dependence on imported oil, brings US and Indian security interests together" (Schaffer, 2009, p. 45). Clearly it is in the national interest of both the United States and India to defend not only free trade but also freedom of navigation.

\section{Conclusion}

India was either non-aligned or aligned with the Soviet Union throughout the Old Cold War. The argument against socialism was however reinforced "by India's own dismal performance in the decades after independence, as well as by the failure of the Soviet Union and other Communist states" (Lal, 2006, p. 3). Yet, in spite of India's persistent economic problems and in spite of the collapse of the USSR, the struggle between communism and capitalism is far from over. The left still poses a threat to both prosperity and peace. This is true in terms of socialism within India and other countries including the United States. It is also true in terms of the New Cold War involving China.

"The general public perception is that the gap between the Indian and American worldviews is still rather wide ... (inasmuch as) the international power structures that India would deem preferable to ... American hegemonism ... are 'polycentrism' and 'multipolarity"' (Hoffmann, 2002, p. 216, 227). But the rise of the left in within the United States is quickly reducing that gap. "Democrats (in the US) and Indian 'pragmatists' are thinking in close proximity ... where the Indian side has a sense that multipolarity will evolve over time, and where Democrats can concede that multipolarity is either a possibility or a certainly" (ibid, p. 239).

When it comes to "reflexive anti-Americanism" (ibid, 2002, p. 241), India is in competition with the United States itself insofar as academia is concerned. Masochism is "de rigueur among American intellectuals, eager to blame their country and its government for most of the evils besetting the world" (Brooks, 2008, p. 129). But a 
likeness between the US and India in some respects, especially a perverse likeness, does not guarantee a likeness in all respects. "Despite democratic commonality between the US and India, Washington had no difficulty in aligning itself with Pakistan - a theocratic and mostly a military dictatorship - and later with China (a secular dictatorship), against India" (Malik \& Kapur, 2002, p. 17). Likewise, Delhi had no difficulty in aligning itself with the USSR (another secular dictatorship). And,"in the wake of the Soviet Union's collapse, India also worked to maintain a relationship with Russia" (Mohan, 2006, p. 22).

Being "an English speaking democracy ... did not prevent ... (India) from being an ally of the Soviet Union, and later Russia, for more than 30 years ... (and) a leading global critic ... (of the United States) for more than 40" (Sieff, 2009, p. 3). But, even if the US and India were not always friends, they were never enemies. And, the two countries are in many ways more alike than different. Compared, for instance, to the Asian Tigers of Taiwan, South Korea, Singapore, and old Hong Kong, India is not totally dependent upon international trade "a characteristic it shares with the US ... (Instead) India and the US have large built-in domestic demand ... thus both economies can better withstand the fluctuations in the world economy" (Gandhi, 2002, p. 330).

Some argue that "the claims of ... economic liberalism ... and democratic peace theory ... are deficient insofar as they fail to take into account the operation of realpolitik" between the US and India (Nayar, 2002, p. 350). Admittedly, "the two countries are no ordinary democracies; the US is the most powerful, and India is the most populous" (Nayar, 2002, p. 381). And, admittedly, India is more socialist whereas the US is more capitalist. But, in spite of nuclear tests on the part of India and economic sanctions on the part of the US, they continue to engage in trade with one another and to refrain from war with one another.

“After September 11, (2001,) India was the first country to offer the United States use of its facilities in its fight against terrorism ... (then) in 2002, India agreed to escort sensitive US cargoes through the Strait of Malacca ... (and) signaled the end of its long-standing opposition to US naval presence in the Indian Ocean" (Schaffer, 2009, p. 75, 77). India, like the US, is doing its best to promote trade and keep peace in the world.

"In his essay, 'The End of History and the Last Man', which he wrote after the collapse of the USSR ... Francis Fukuyama asserted ... we are witnessing not just the end of the (Old) Cold War ... but ... the universalization of Western liberal democracy" (Kapur, 2002, p. 533). But after the attacks of 9-11-2001, it seemed there were "casualties in addition to the human tragedy at the World Trade Center and the Pentagon ... (including) the dream of a new world order ... based on ... globalization or economic and peace-oriented multilateralism, arms control, and conflict resolution or regulation" (ibid, p. 534).

"Al-Qaida was ... a non-state organization and a transnational one ... (that) took advantage of the weakening of the nation-state in a globalizing world" and in particular the weakening of borders (Picco, 2003, p. 16). But "paradoxically, Osama bin Laden (the leader of Al-Qaida) ... contributed to the continued geopolitical marginalization and isolation of the Arab, if not the entire Islamic world" (ibid, p. 17). "Had bin Laden read Roman history, he would have known that it is unwise to turn against all enemies simultaneously, for it is the surest way to unify them" (ibid, p. 18). "Whether the United States, Russia, China, and India share equally the sense of having been, and of continuing to be, primary targets for Al-Qaida, they are hostile to Islamic fundamentalism" given the attacks in New York, Chechnya, Xinjiang, and Kashmir (ibid, p. 19).

"America and Russia are now partners in the fight against terrorism ... (and) there is now a better appreciation of the Indian argument" against Islamic terrorism ... (indeed, it seems that) terrorism has created new relationships between America and Russia, while it has consolidated emerging relationships such as between America and India" (Kapur, p. 541-2)."India and Russia ... share an interest in keeping Central Asia stable and in preventing the emergence of Islamic governments there ... (and) the United States along with "Russia can make common cause with India in trying to keep down (both) Chinese and Islamic influence in Central Asia" (Schaffer, 2009, p. 176-177).

"The US's underlying strategic view is that India is a second Asian giant - capitalist, multicultural, secular, and democratic - which will ... limit China's aspiration to global hegemony" (Shuja, 2006, p. 43). "India has proven mechanisms for the peaceful transfer of power and the ability to withstand terrible internal conflicts ... (and) India will remain younger and dynamic well into the middle of the $21^{\text {st }}$ century" (ibid, p. 46). "India has become the world's largest arms importer, and American exporters are benefiting ... however India ... now does more trade with China ... than it does with America" (Less than Allies, 2012). Nonetheless, India's "relations with America have thrived ever since a civil nuclear deal agreed with (President) George W. Bush seven years ago ... (and) cultural ties via India's diaspora in America help" as well (Aim Higher, 2012, p. 14).

Indians and Americans are in the process of getting to know one another. And speaking English is a big help. "Trade between India and the United States, the importing into the United States of talented professionals from 
India, the outsourcing of services to India, Indian students studying in the United States, tourists from India, (and) international news media ... have all contributed to increased exposure ... to India" in the US (Lumb\&Lall, 2006, p. 47). In addition, Americans are now able to view movies made in Bollywood, aka Mumbai, since Netflix has a separate genre under foreign films for Indian movies. And, it's only a matter of time before baby-boomers retire on the subcontinent where the cost of living is substantially less.

Now "freed from the constraints of the (Old) Cold War, the United States and India share a number of common concerns and interests. Both have much to fear from global terrorism, share concerns about a rising China, are desirous of maintaining access to the oil resources of the Persian Gulf, and have important trade complementarities" (Ganguly, 2003, p. 30). But common interests do not necessarily result in strong alliances. "The inequality of power between the two countries, the absence of a habit of political cooperation between them, and the remaining bureaucratic resistance to deeper engagement in both capitals will continue to limit the pace and the scope of strategic cooperation between India and the United States" (Mohan, 2006, p. 25). A stronger bond will no doubt be forged in the heat of some future crisis.

\section{References}

500 Nations. (2012). Indian Casinos Supersite. Retrieved August 22, 2012, from $\mathrm{http}: / / 500$ nations.com/Indian_Casinos.asp

A \& E Television Networks. (2012). 9-11 Attacks. Retrieved August 17, 2012, from History.com: http://www.history.com/topics/9-11-attacks/videos?mkwid=s4sZXGLHl_pcrid_14041789158_pkw_world\% 20 trade $\% 20$ center\%209\%2011_pmt_b\&utm_source $=$ google\&utm_medium $=c \overline{p c} \& u t m \_$term $=$world $\% 20$ trad e\%20center\%209\%2011\&utm_campaign=G_September+11\&paidlink=1\&cmpid=PaidSearch

Afghan Chamber of Commerce. (2012). White Huns. Retrieved October 23, 2012, from http://www.afghanchamber.com/history/White_Huns.htm

Ahmad, A. (2002). US-India science and technology relations: A socio-political analysis. In A. Kapur, Y. Malik, H. Gould, \& A. Rubinoff (Eds.), India and the United States in a changing world (pp. 42-82). New Delhi: Sage Publications.

Aim Higher. (2012, September 29). Economist (Special Report), p. 4.

An Area of Darkness. (2012, August 2). Economist, p. 35.

Asian Welfare States. (2012, September 8). Economist, p. 26.

Asia's Next Revolution. (2012, September 8). Economist, p. 11.

At the front of the Back Office. (2012, June 23). Economist, p. 68.

Ataman, M. (2003). The Impact of non-state actors on world politics: A challenge to nation-states. Turkish Journal of International Relations, 2(1), 42-66.

Badly Drawn. (2012, May 19). Economist, p. 49.

Barrier, N. G. (2002). India and America - A half century of academic and scholarly exchange, 1947-99. In A. Kapur, Y. Malik, H.Gould, \& A.Rubinoff (Eds.), India and the United States in a changing world (pp. 83-105). New Delhi: Sage Publications.

Basham, A. (2004). Wonder that was India (3rd ed.). Oxford: Pan Macmillan.

Battle Description. (2012). Kushan Invasion of India. Retrieved October 23, 2012, from $\mathrm{http}$ ://battledescription.com/kushan-invasion-of-india/

Bhoumik, A. (2005). Democratic responses to terrorism: A comparative study of the United States, Israel, and India. Denver Journal of International Law and Policy, 33(2).

Blood in the Corridor. (2012, March 31). Economist, pp. 50-51.

Booted Upstairs. (2012, July 21). Economist, p. 34.

Boston, T., \& Nair-Reichert, U. (2003). Affirmative action: Perspectives from the United States, India, and Brazil. The Western Journal of Black Studies, 27(1), 3-14.

Brooks, S. (2008). Anti-Americanisms in world politics. Canadian Foreign Policy, 14(1), 129-132.

Building India Inc. (2011, October 22). Economist.

Case for the Defense. (2012, January 7). Economist. 
Chandhoke, N. (2007). Negotiating linguistic diversity: A comparative study of India and the United States. In K. Bajpai (Ed.), Democracy and diversity: India and the American experience (pp. 107-143). Oxford: Oxford University Press.

Charters of Freedom. (1787). Constitution of the United States. Retrieved August 25, 2012, from $\mathrm{http} / / /$ www.archives.gov/exhibits/charters/constitution_transcript.html

Chaturvedi, S., \& Choudhury, S. (2012, July 30). Massive Power Outage Paralyzes North India; Chaos Affecting Area of 369 Million Underlines the Inadequacy of Government's Efforts to Improve Energy Infrastructure. Wall Street Journal. Retrieved August 1, 2012, from http://search.proquest.com.libproxy.troy.edu/docview/1030071775/abstract/138495CF88F37BDFB71/8?acc ountid $=38769$

Chaudhuri, B. (2011). Skilled migration from India to the United States: Contextualization in the backdrop of global economic crisis. International Journal of Economics and Business, 10(2-3), 249-266.

Christie, P., Kwon, I., Stoeberl, P., \& Baumhart, R. (2003). A cross-cultural comparison of ethical attitudes of business managers: India, Korea, and the United States. Journal of Business Ethics, 46(3), 263-287. http://dx.doi.org/10.1023/A:1025501426590

CIA. (2011). Country comparison: Population. Retrieved July 9, 2012, from https://www.cia.gov/library/publications/the-world-factbook/rankorder/2119rank.html

CIA. (2012). Country comparison: Area. Retrieved September 29, 2012, from https://www.cia.gov/library/publications/the-world-factbook/rankorder/2147rank.html"

City-Data. (2012). US Territories. Retrieved October 25, 2012, from http://www.city-data.com/forum/u-s-territories/1365259-us-census-releases-first-data-sets.html

Commonwealth. (2012). Who We Are. Retrieved October 5, 2012, from http://www.thecommonwealth.org/subhomepage/191086/

Company that Ruled the Waves. (2011, December 17). Economist.

Craig, K. (1995). Empirical Tests of Dependency Theory in the Contemporary Commonwealth Caribbean (Doctoral dissertation, Univeristy of Mississippi). Dissertation Abstracts International, 57(01A), 426.

Craig, K. (2010). The new world order. International Journal of Public Administration, 33, 414-420. http://dx.doi.org/10.1080/01900691003750739

Craig, K. (2011). The blame game in international relations. National Social Science Journal, 35(2), 43-54.

Craig, K. (2012). No child left bewildered: Using phonetic English as a lingua franca. International Journal of Business and Social Science, 3(8), pp. 76-82.

De Souza, P. (2007). Decentralization: Explorations of local government in India and the United States. In K. Bajpai (Ed.), Democracy and diversity: India and the American experience (pp. 262-297). Oxford: Oxford University Press.

Duff-Brown, B. (1994, November 20). Scholars Continue to Reveal Mao's Monstrocities. Los Angeles Times. Retrieved September 18, 2012, from http://www.paulbogdanor.com/left/china/deaths2.html

Encyclopaedia Britannica. (2012). David IV. Retrieved September 30, 2012, from http://www.britannica.com/EBchecked/topic/152619/David-IV

EPA. (2012). Demographics. Retrieved August 19, 2012, from http://www.epa.gov/oecaagct/ag101/demographics.html

Farewell to Incredible India. (2012, June 9). Economist, p. 14.

Farooquie, J. (2011). A review of e-government readiness in India and the UAE. International Journal of Humanities and Social Science, 1(1), 6-13.

Fodor's. (2011). Essential India. New York: Random House.

Free Exchange. (2012, March 31). Economist, p. 87.

Future is Black. (2012, January 21). Economist.

Gaan, N. (2007). India and the United States: From estrangement to engagement. Delhi: Kalpaz Publications.

Gajanan, S., \& Radhakrishnan, S. (2002). Policy retailation and inefficiency. In A. Kapur, Y. Malik, H. Gould, \& A. Rubinoff (Eds.), India and the United States in a changing world (pp. 106-143). New Delhi: Sage 
Publications.

Gandhi, P. (2002). India-US economic relations: A perspective. In A. Kapur, Y. Malik, H. Gould, \& A. Rubinoff (Eds.), India and the United States in a changing world (pp. 328-348). New Delhi: Sage Publications.

Ganguly, S. (2003). The start of a beautiful friendship: The United States and India. World Policy Journal, Spring, 25-30.

Ganguly, S., \& Scobell, A. (2005). India and the United States: Forging a security partnership? World Policy Journal, Summer, 37-43.

Gasping for Breath. (2011, December 17). Economist.

Ghosh, R., \& Chaudhuri, S. (2009). Inter-generational differences in individualism/collectivism orientations: Implications for outlook towards HRD/HRM practices in India and the United States. New Horizons in Adult Education and Human Resource Development, 23(4), 5-21.

Glazer, N. (2007). Minorities and India's democracy. In K. Bajpai (Ed.), Democracy and diversity: India and the American experience (pp. 144-191). Oxford: Oxford University Press.

Goel, S. R. (1994). The Story of Islamic Imperialism in India (2nd ed.). New Delhi: Voice of India.

Gould, H. (2002). The reasons why: The US failure to control the nuclear agenda in South Asia. In A. Kapur, Y. Malik, H. Gould, \& A. Rubinoff (Eds.), India and the United States in a changing world (pp. 144-215). New Delhi: Sage Publications.

Gowda Saraswat Brahmins of Kerala. (2012). Time Line of India. Retrieved September 13, 2012, from http://www.gsbkerala.com/timelindia.htm

Harms, W. (1996, March 14). China'a Great Leap Forward. The University of Chicago Chronicle, 15(13). Retrieved September 18, 2012, from http://chronicle.uchicago.edu/960314/china.shtml

Hathaway, R. (2002). Coming of age: Indian-Americans and the US Congress. In A. Kapur, Y. Malik, H. Gould, \& A. Rubinoff (Eds.), India and the United States in a changing world (pp. 386-411). New Delhi: Sage Publications.

Hathaway, R. M. (2001). Unfinished passage: India, Indian Americans, and the US Congress. The Washington Quarterly, 24(2), 21-34. http://dx.doi.org/10.1162/016366001300092977

Hoffmann, S. (2002). Indo-US strategic worldviews. In A. Kapur, Y. Malik, H. Gould, \& A. Rubinoff (Eds.), India and the United States in a changing world (pp. 216-244). New Delhi: Sage Publications.

Hold Your Nose. (2012, August 18). Economist, p. 63.

Home of the Roma Kings. (2012, September). National Geographic, p. 140.

In Vinod We Trust. (2012, August 11). Economist, p. 34.

Indian Mirror. (2012). Muslim Invasions. Retrieved October 23, 2012, from http://www.indianmirror.com/history/hist4.html

India's Identity Revolution. (2011, November 17). Economist.

India's Poor Starve as Politicians Steal their Food. (2012, September 10). Bloomberg Businessweek, p. 17.

Infrastruggles. (2011, December 31). Economist.

International Centre for Prison Studies. (2012). Entire world: Prison population rates per 100,000 of national $\begin{array}{lllll}\text { population. } & \text { Retrieved } & \text { August } & 17, & \text { from }\end{array}$ http://www.prisonstudies.org/info/worldbrief/wpb_stats.php?area=all\&category=wb_poprate

Kapur, A. (2002). The aftermath of 11 September: Changing geo-political equations and Indo-US relations. In A. Kapur, Y. Malik, H. Gould, \& A. Rubinoff (Eds.), India and the United States in a changing world (pp. 533-543). New Delhi: Sage Publications.

Kenny, C. (2012, October 1). Bloomberg Businessweek, p. 10-11.

Khare, R. (2002). Two disengaged cultures, two distant democracies: Anthropological notes on Indian and American political ethos. In A. Kapur, Y. Malik, H. Gould, \& A. Rubinoff (Eds.), India and the United States in a changing world (pp. 245-296). New Delhi: Sage Publications.

Lal, R. (2006). Understanding China and India: Security implications for the United States and the world. Westport, CT: Praeger Security International. 
Lambeth, B. (2012, September). Air War at the Top of the World. Air Force Magazine.

Language of Internationa Business. (1965). International Executive, 7(3), 9-10. http://dx.doi.org/10.1002/tie.5060070305

Last Mile. (2012, March 20). Economist.

Less than Allies, More than Friends. (2012, June 16). Economist, p. 45.

Lijphart, A. (2007a). The importance of India-United States comparison for political science. In K. Bajpai (Ed.), Democracy and Diversity: India and the American Experience (pp. 1-13). Oxford: Oxford University Press.

Lijphart, A. (2007b). Democratic institutions and ethnic/religious pluralism: Can India and the United States learn from each other - and from the smaller democracries. In K. Bajpai (Ed.), Democracy and diversity: India and the American experience (pp. 14-49). Oxford: Oxford University Press.

Lines of History. (2012, March 24). Economist, p. 87.

Linz, J., Stepan, A., \& Yadav, Y. (2007). 'Nation state' or 'State nation'?: India in comparative perspective. In K. Bajpai (Ed.), Democracy and diversity: India and the American experience (pp. 50-106). Oxford: Oxford University Press.

Losing its Magic. (2012, March 24). Economist, p. 14.

Lumb, R., \& Lall, V. (2006). Perceptions of the quality of products made in India by consumers from the United States: A longitudinal analysis. International Journal of Economics and Business, Special Issue, 47-60.

Magic Number. (2012, January 14). Economist.

Magical Mistry Tour. (2011, November 26). Economist.

Malik, Y., \& Kapur, A. (2002). India and America - Engaging each other in a changing world. In A. Kapur, Y. Malik, H. Gould, \& A. Rubinoff (Eds.), India and the United States in a changing world (pp. 13-41). New Delhi: Sage Publications.

Marx, K., \& Engels, F. (1848). Manifesto of the Communist Party, Chapter 4. Retrieved August 29, 2012, from http://www.marxists.org/archive/marx/works/1848/communist-manifesto/ch04.htm

Masala Mittelstand. (2012, August 11). Economist, p. 55.

Megahurts. (2012, February 11). Economist.

Minimum City. (2012, June 9). Economist, p. 77.

Mixed Blessings. (2102, March 3). Economist.

Mohan, C. (2006). India and the balance of power. Foreign Affairs, 85(4), 17-26. http://dx.doi.org/10.2307/20032038

Monsoon, or Later. (2012, July 28). Economist, p. 33.

More than Pomp and Frolics. (2011, December 17). Economist.

Must it be a Gandhi. (2011, November 19). Economist.

Nayar, B. (2002). US economic sanctions against nuclear India: Implications for economic liberalism and democratic peace theory. In A. Kapur, Y. Malik, H. Gould, \& A. Rubinoff (Eds.), India and the United States in a changing world (pp. 349-385). New Delhi: Sage Publications.

Neglected Crisis. (2012, August 25). Economist, p. 29.

Nessman, R. (2012, July 31). Electricity grids fail over half of India. Retrieved August 1, 2012, from http://hosted2.ap.org/OREUG/topstories/Article_2012-07-31-India-Power\%20Outage/id-e2bb41486e224e8 $1 \mathrm{~b} 4 \mathrm{f} 130 \mathrm{f} 1 \mathrm{f} 475 \mathrm{c} 526$

Nuclear Profusion. (2012, August 25). Economist, p. 33.

Perez, J., Horwitz, G., \& Kindall, D. (2012, July). Collision Course: Why Democrats Must Back Entitlement Reform. Retrieved August 17, 2012, from http://content.thirdway.org/publications/564/Third_Way_Report_-_Collision_Course_Why_Democrats_Mu st_Back_Entitlement_Reform.pdf

Perry, L. (2006, July-September). Neo-liberal labor market reforms and work stoppages: Comparisons of India, Indonesia, the United States, and Australia. South Asian Journal of Management, 7-30.

Pew Forum. (2011, January). The Future of the Global Muslim Population. Retrieved July 9, 2012, from 
http://features.pewforum.org/muslim-population/

Picco, G. (2003). New entente after September 11? The United States, Russia, China, and India. Global Goverance, 9(1), 15-21.

Pickering, T. (2011, June). Former US Ambassador to India on Charting the Future of US-India Relations. Retrieved July 25, 2012, from http://www.nbr.org/downloads/pdfs/outreach/NBR_IndiaCaucus_June2011.pdf

Pondering the Past. (2012, September 15). Economist, p. 77.

Pulling Every Lever. (2012, February 4). Economist.

Rain, D., Long, J., \& Ratcliffe, M. (2007). Measuring population pressure on the landscape: Comparative GIS studies in China, India, and the United States. Popul Environ, 28, 321-336. http://dx.doi.org/10.1007/s11111-007-0055-4

Red Retreat. (2011, December 3). Economist.

Reform by the Numbers. (2012, January 14). Economist.

Rich Pickings. (2012, March 17). Economist, p. 69.

Rosenbloom, D. (1981). Federal Equal Employment Opportunity: Is the polarization woth the preference? Southern Review of Public Administration, 5(1), 63-70.

Rubinoff, A. (2002). Legislative perceptions of Indo-American relations. In A. Kapur, Y. Malik, H. Gould, \& A. Rubinoff (Eds.), India and the United States in a changing world (pp. 412-457). New Delhi: Sage Publications.

Running with the Bulls. (2012, March 3). Economist.

Salvation Army. (2012). Invasion. Retrieved October 23, 2012, from http://web.salvationarmy.org/ind\%5Cwww_ind.nsf/vw-sublinks/80256E520050A2E280256CAF002F6659? openDocument

Sanujit. (2011, February 12). Cultural Links between India and the Greco-Roman. Retrieved August 30, 2012, $\mathrm{http}: / /$ www.ancient.eu.com/article/208/

Schaffer, T. (2009). India and the United States in the 21st century: Reinventing partnership. Washington, DC: Center for Strategic and International Studies.

Sharma, A. (2005). Reservation and affirmative action: Models of social integration in India and the United States. New Delhi: Sage Publications.

Shoots, Greens and Leaves. (2012, June 16). Economist, p. 68.

Shuja, S. (2006). The United States and India. International Journal on World Peace, XXIII(2), 35-47.

Shwayder, M. (2012, September 11). US Embassy Attacks. Retrieved October 26, 2012, from http://www.ibtimes.com/us-embassy-attacks-and-bombings-recent-history-782665

Sieff, M. (2009). Shifting superpowers: The new and emerging relationship between the United States, China, and India. Washington, DC: Cato Institute.

Silence of the Bollygarchs. (2012, August 18). Economist, p. 61.

Smith, V. A. (1914). The Early History of India: From 600 BC to the Muhammadan Conquest (3rd ed.). Oxford: Clarendon Press.

Smoke without Fire. (2012, June 2). Economist, p. 54.

Sperling, J. (2002). Ideals or self-interest? The Indian nuclear deterrent and American foreign policy. In A. Kapur, Y. Malik, H. Gould, \& A. Rubinoff (Eds.), India and the United States in a changing world (pp. 458-498). New Delhi: Sage Publications.

Spillane, E. (1913). Lucas Vásquez de Ayllón. Retrieved August 18, 2012, from http://en.wikisource.org/wiki/Catholic_Encyclopedia_(1913)/Lucas_V\%C3\%A1squez_de_Ayll\%C3\%B3n

Sridharan, E. (2007). Democracy within parties and the accomodation of diversity: Comparing India and the United States. In K. Bajpai (Ed.), Democracy and diversity: India and the American experience (pp. 192-224). Oxford: Oxford University Press.

Srivastava, A. (2011). Ownership structure and corporate performance: Evidence from India. International 
Journal of Humanities and Social Science, 1(1), 23-29.

State Symbols USA. (2012). United States Seal. Retrieved July 21, 2012, from http://www.statesymbolsusa.org/National_Symbols/USA_Seal.html

States and Union Territories. (2012). Retrieved October 25, 2012, from http://india.gov.in/knowindia/state_uts.php

Stepan, A. (2007). Federalism, multi-national societies, and negotiating a democratic 'state-nation': A theoretical framework, the Indian model and a Tamil case study. In K. Bajpai (Ed.), Democracy and diversity: India and the American experience (pp. 225-261). Oxford: Oxford University Press.

Stewart Jr., W., May, R., \& Kalia, A. (2008). Environmental perceptions and scanning in the United States and India: Convergence in entrepreneurial information seeking? Entrepreneurship Theory and Practice, January, 83-106.

Taking Pains. (2012, September 8). Economist, p. 62.

Tales of the Unexpected. (2012, February 18). Economist.

Translation: Shape-Shifting. (2011, September 10). Economist, p. 96.

Travellers Checked. (2012, May 19). Economist, p. 74.

Tremblay, R. (2002). Indo-US relations and the Kashmir issue. In A. Kapur, Y. Malik, H. Gould, \& A. Rubinoff (Eds.), India and the United States in a changing world (pp. 499-532). New Delhi: Sage Publications.

Tummala, K. K. (1999). Policy of preference: Lessons from India, the United States, and South Africa. Public Administration Review, 59(6), 495-508. http://dx.doi.org/10.2307/3110298

U. S. Census Bureau. (2010). Country Rankings. Retrieved July 9, 2012, from http://sasweb.ssd.census.gov/cgi-bin/broker

UN Security Council. (2012). Membership in 2012. Retrieved August 17, 2012, from http://www.un.org/sc/members.asp

UN Statistical Division. (2009-2010). Population: Latest available census and estimates. Retrieved July 9, 2012, from http:/unstats.un.org/unsd/demographic/products/vitstats/serATab2.pdf

Unfinished Journey. (2012, March 24). Economist, p. 27.

USDA. (2012). Wheat Area, Yield, and Production. Retrieved August 19, 2012, from http://www.fas.usda.gov/psdonline/psdreport.aspx?hidReportRetrievalName=BVS\&hidReportRetrievalID= 448\&hidReportRetrievalTemplateID $=1$

Vickery Jr., R. (2011). The Eagle and the Elephant: Strategic Aspects of US-India Economic Engagement. Washington, DC: Woodrow Wilson Center Press.

Wadhwa, V. (2008). A disciple becomes the guru: Should the United States learn from India? Harvard International Review, Fall, 72-75.

Wadhwa, V., Gereffi, G., Rissing, B., \& Ong, R. (2007). Where the engineers are. Issues in Science and Technology, Spring, 73-84.

Walt, S. M. (1998). International relations: One world, many theories. Foreign Policy, Spring, 29-46. http://dx.doi.org/10.2307/1149275

Welcome Slap in the Face. (2012, March 2012). Economist.

Wholesale Reform. (2012, November 25). Economist.

Wikipedia. (2012). India: State and Union Territories. Retrieved September 14, 2012, from http://www.google.com/imgres?q=free+maps + of + india\&hl=en\&sa=X\&biw=1536\&bih=744\&tbm=isch\&pr $\mathrm{md}=$ imvnsa\&tbnid=arslgFvgkNSFDM:\&imgrefurl=http://en.wikipedia.org/wiki/File:India-map.jpg\&docid =oqVQ_0NIhxc3BM\&imgurl=http://upload.wikimedia.org/wikipedia/en/4/4e/In

World Bank. (2012). GDP per capita. Retrieved October 22, 2012, from http://data.worldbank.org/indicator/NY.GDP.PCAP.CD

Yongyi, S. (2012, July 23). Chronology of Mass Killings during the Chinese Cultural Revolution. Retrieved September 18, 2012, from http://www.massviolence.org/Chronology-of-Mass-Killings-during-the-Chinese-Cultural 